University of Nebraska - Lincoln

DigitalCommons@University of Nebraska - Lincoln

Zea E-Books Collection

Zea E-Books

7-1-2021

\title{
Parasites: The Inside Scoop
}

Scott Gardner

University of Nebraska - Lincoln, slg@unl.edu

Judy Diamond

University of Nebraska - Lincoln, jdiamond1@unl.edu

Gábor R. Rácz

University of Nebraska - Lincoln, gracz2@unl.edu

Brenda Lee

University of Nebraska-Lincoln, brenda.lee@huskers.unl.edu

Follow this and additional works at: https://digitalcommons.unl.edu/zeabook

Part of the Parasitology Commons, and the Science and Mathematics Education Commons

\section{Recommended Citation}

Gardner, Scott; Diamond, Judy; Rácz, Gábor R.; and Lee, Brenda, "Parasites: The Inside Scoop" (2021). Zea E-Books Collection. 106.

https://digitalcommons.unl.edu/zeabook/106

This Book is brought to you for free and open access by the Zea E-Books at DigitalCommons@University of Nebraska - Lincoln. It has been accepted for inclusion in Zea E-Books Collection by an authorized administrator of DigitalCommons@University of Nebraska - Lincoln. 


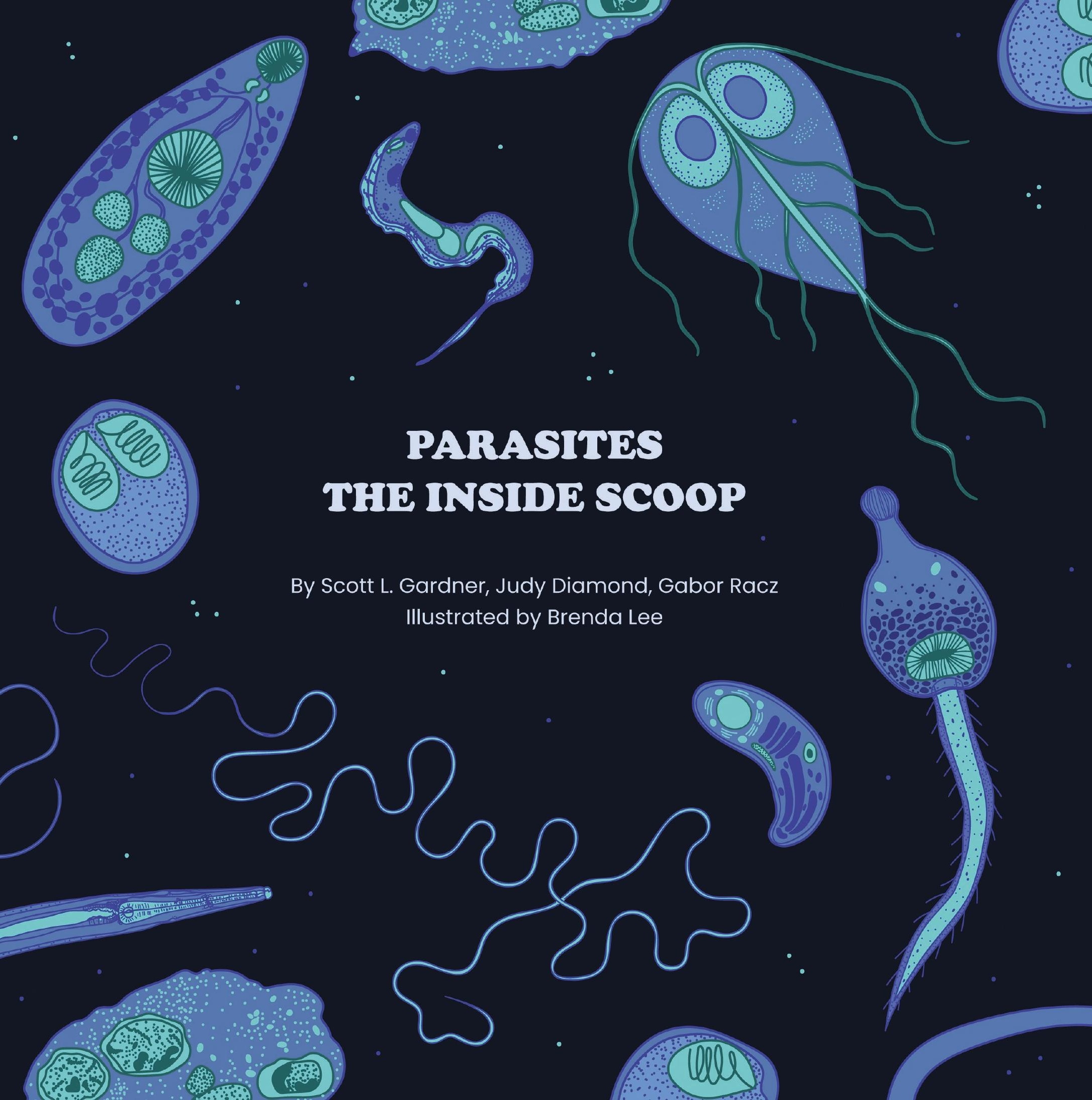




\section{PARASITES THE INSIDE SCOOP}

By Scott L. Gardner, Judy Diamond, Gabor Racz Illustrated by Brenda Lee

Zea Books

Lincoln, Nebraska

2021 


\section{Nebrask ka Lincoln}

$\begin{array}{ll}\text { ISBN 978-1-60962-205-3 } & \text { paperback } \\ \text { ISBN 978-1-60962-206-0 } & \text { ebook } \\ \text { DOI: 10.32873/unl.dc.zea.1302 } & \end{array}$

Zea Books are published by the University of Nebraska-Lincoln Libraries

Electronic (pdf) editions available online at http://digitalcommons.unl.edu/zeabooks/ Print edition available from http://www.lulu.com/spotlight/unlib

UNL does not discriminate based upon any protected status.

Please go to http://www.unl.edu/equity/notice-nondiscrimination

Copyright (c) 2021 Harold W. Manter Laboratory of Parasitology 


\section{Contents}

About Parasites

p. 1

The H. W Manter Laboratory of Parasitology

p. 10

Meet Some Parasites

p. 11

Glossary

p. 26

Resources for Youth

p. 28

About the Authors and Illustrator

p. 29 
We dedicate this book to all young investigators of the natural world. 


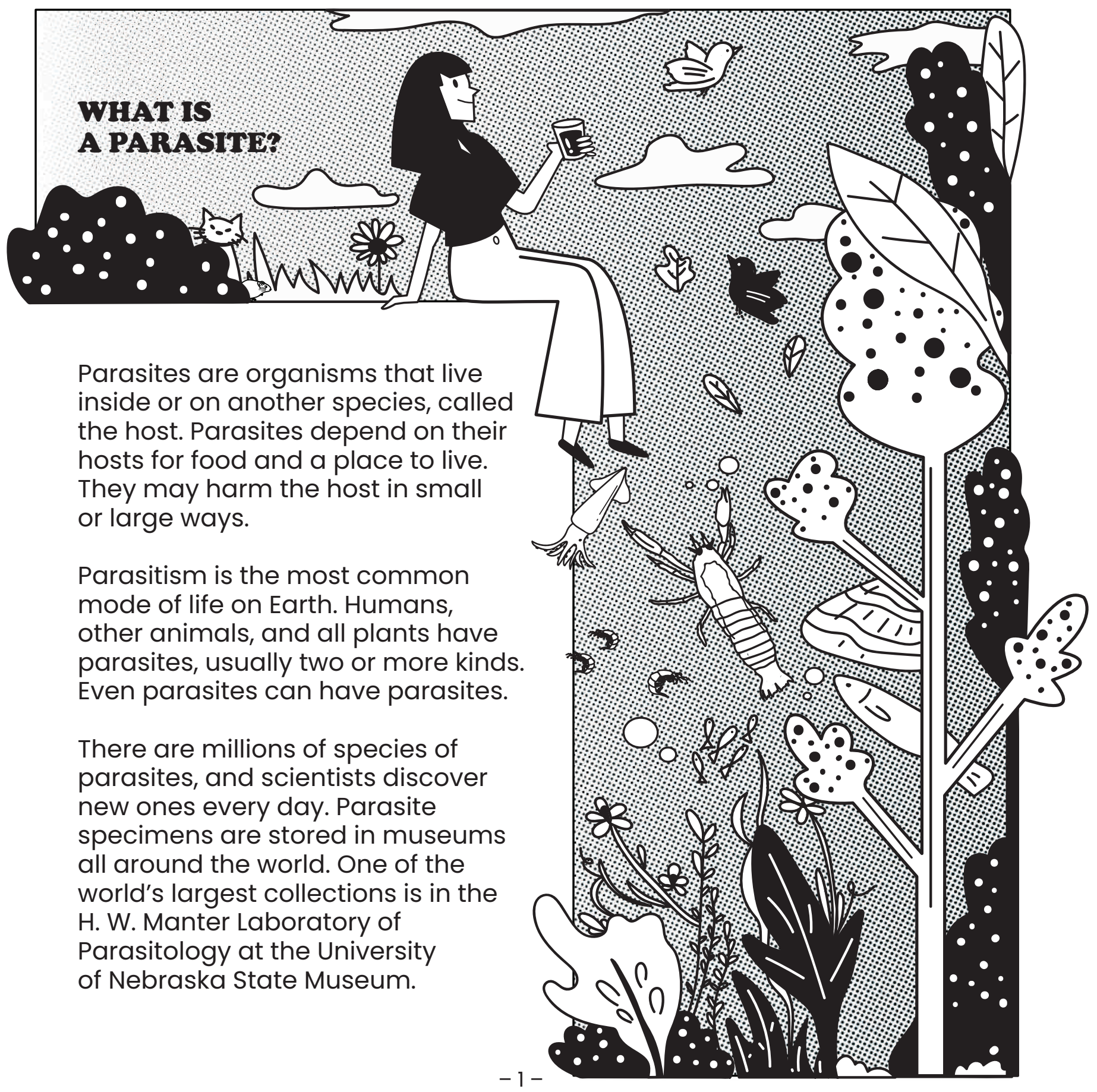




\section{PARASITES AND HOSTS}

Parasites live with their hosts in many ways. One way to think about them is whether they live on the outside or the inside of their hosts. Fleas, ticks, mites, and lice are parasites that live on the outside of their hosts. These are called ectoparasites. Tapeworms, pinworms, flukes, and parasitic protozoa are parasites that live inside their hosts. These typically live in the guts or tissues and are called endoparasites.

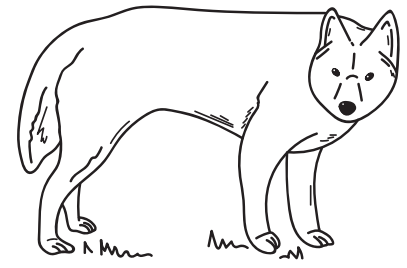

Do parasites need hosts? Yes. Parasites need to live in or on other animals or plants to survive. Parasites rely on host species for nutrients and a safe place to live. They rarely kill their host, although they can seriously harm its health.
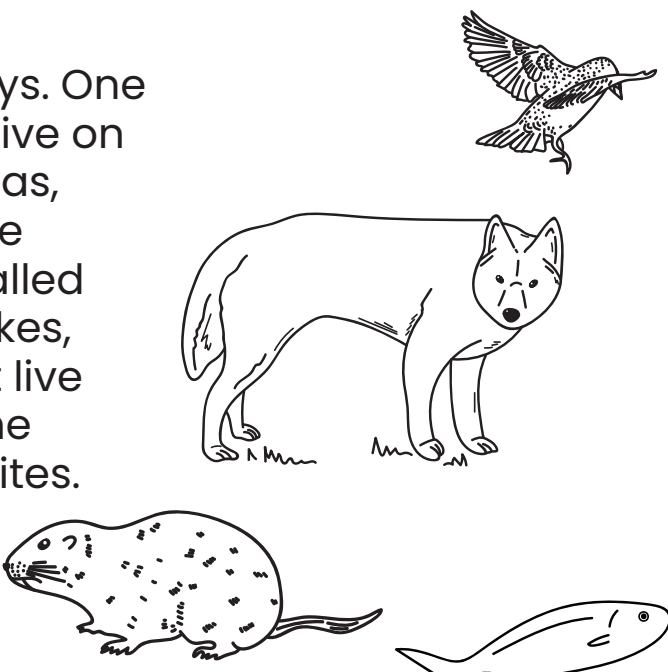

\section{harm its health.}
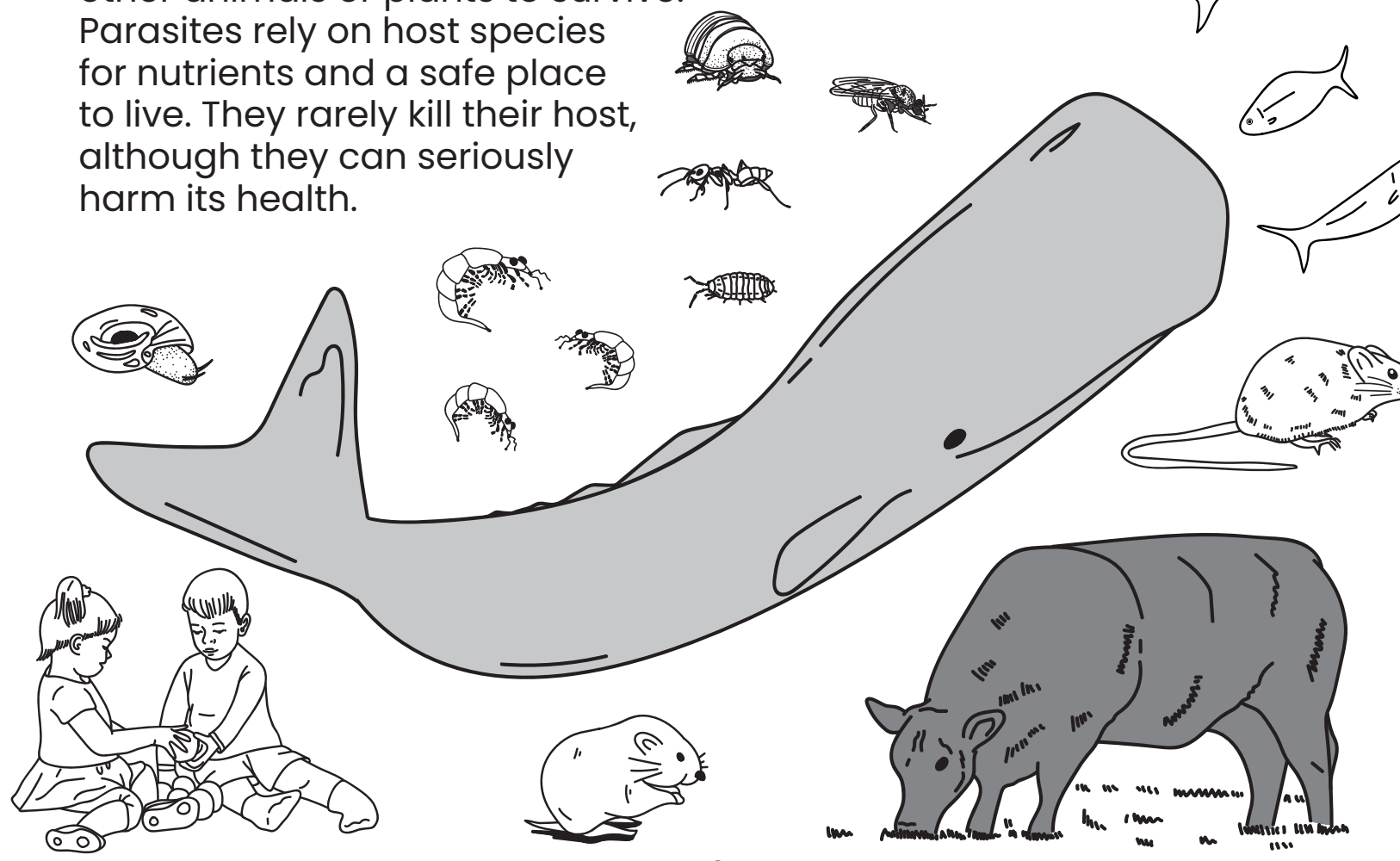
PARASITE LIFE STORIES

Many parasites take a long journey, passing from one host to another while they develop from eggs, to larvae, and then into adults. In their definitive or final hosts, the adults reproduce sexually and produce eggs.
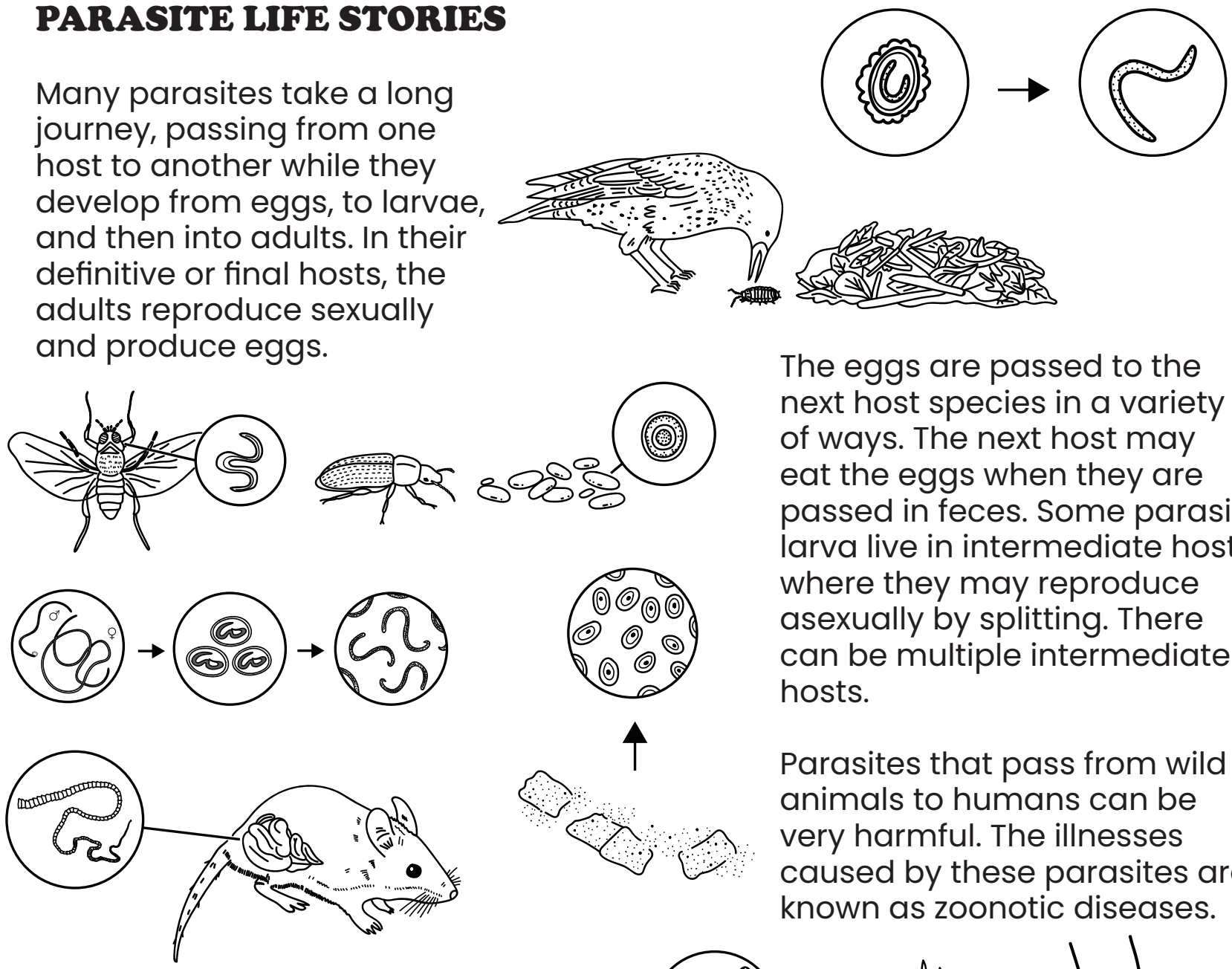

The eggs are passed to the next host species in a variety of ways. The next host may eat the eggs when they are passed in feces. Some parasite larva live in intermediate hosts, where they may reproduce asexually by splitting. There can be multiple intermediate hosts.

Parasites that pass from wild animals to humans can be very harmful. The illnesses caused by these parasites are known as zoonotic diseases.

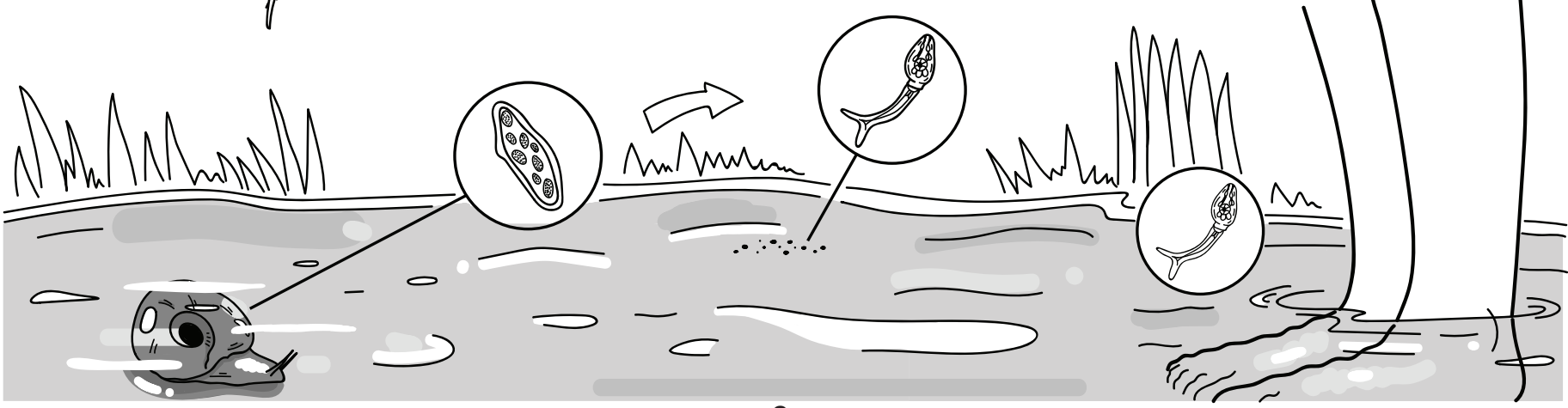




\section{A SUCCESSFUL LIFESTYLE}

Parasites find food, mates, and a place to live just like other animals do. They are as important and successful as free-living plants and animals. Parasites come from all parts of the tree of life, and they can be found in every habitat, on all continents, and in every ocean.
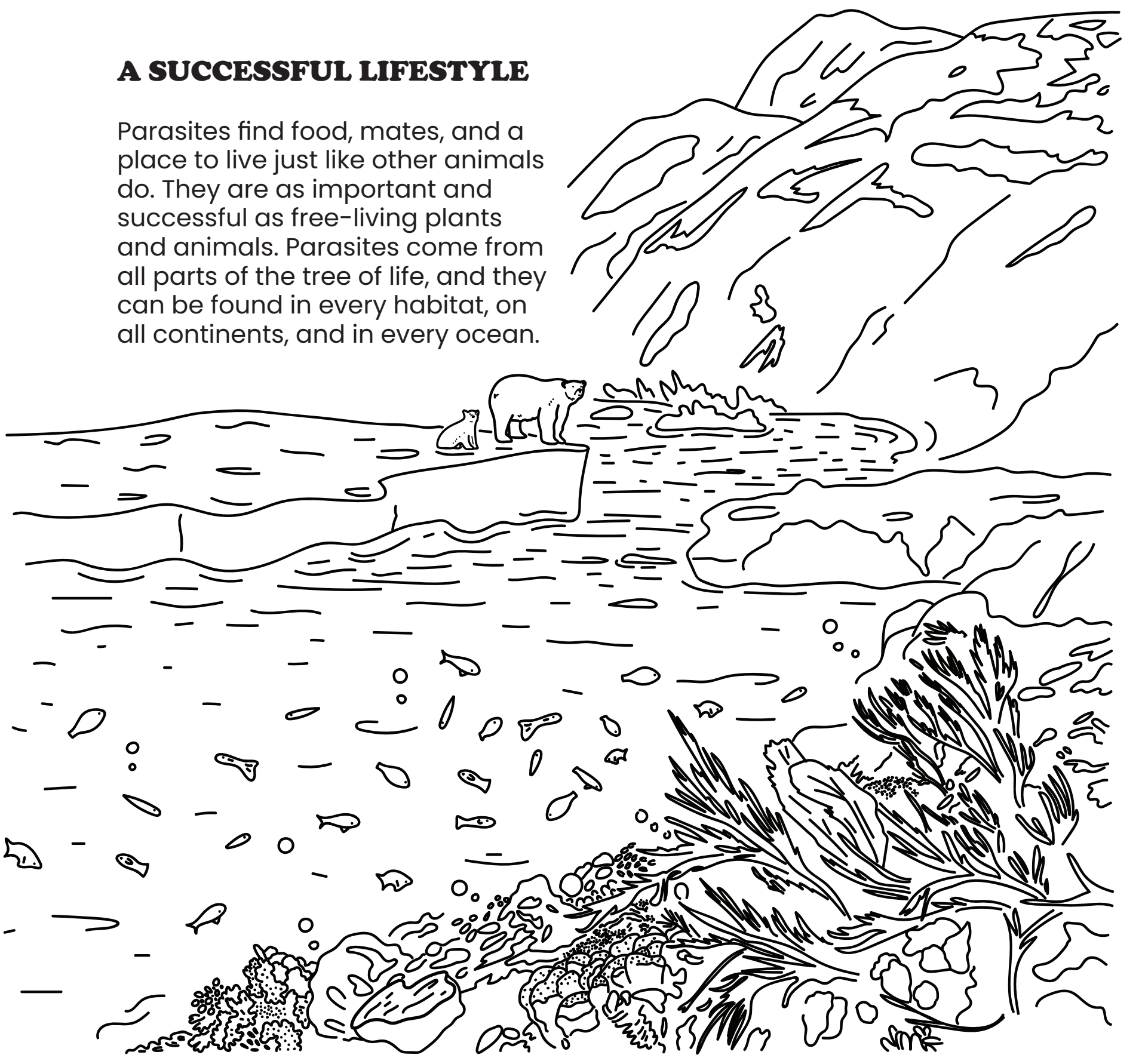

\footnotetext{
$-4-$
} 


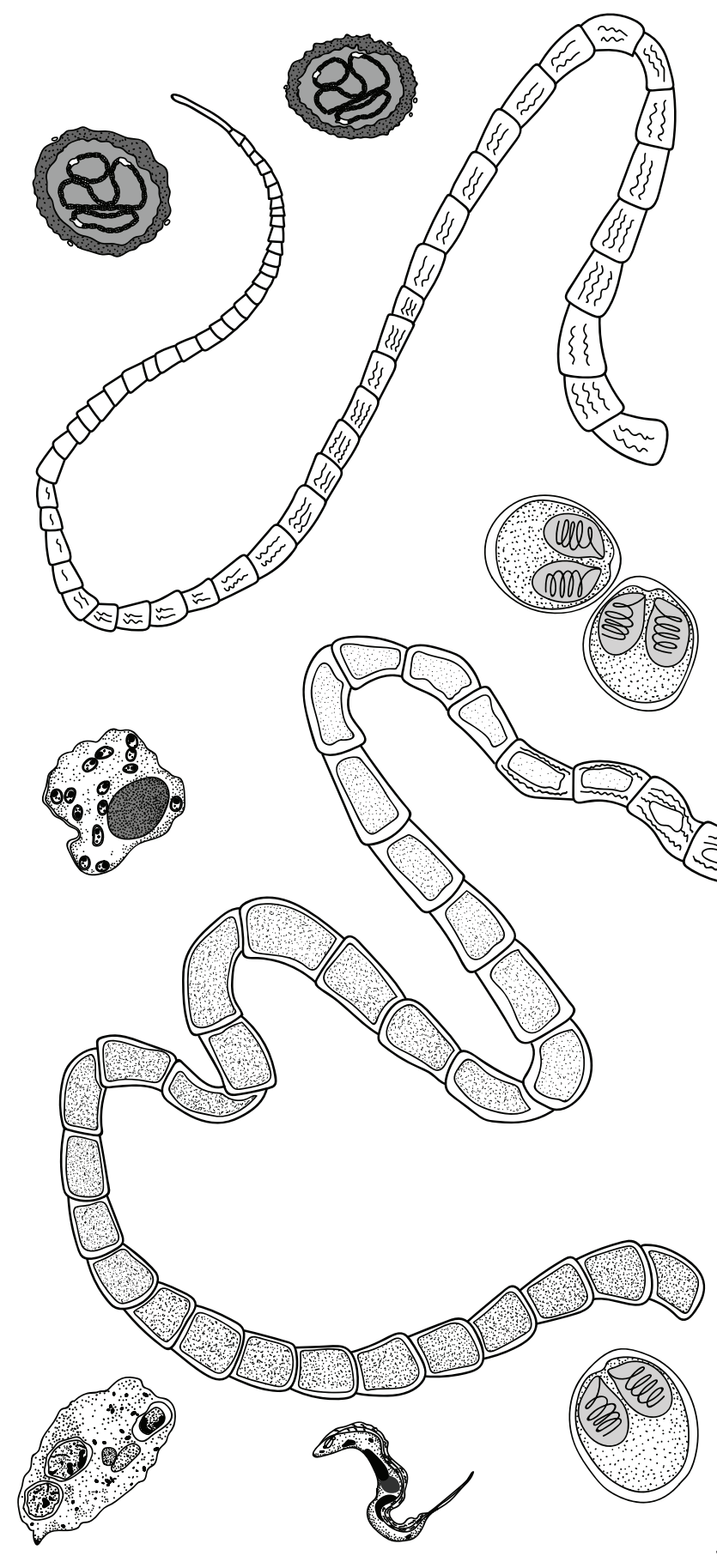

\section{PARASITES LARGE AND SMALL}

Parasites can range in size from the microscopic to the downright massive. For example, the broad fish tapeworm can live in bears and humans and reach lengths of thirty feet or more. The whale tapeworm can exceed one hundred feet in length. That's about as long as three school buses! Compare this to the tiny microfilariae of heartworm nematodes in dogs that are thinner than a couple of red blood cells.

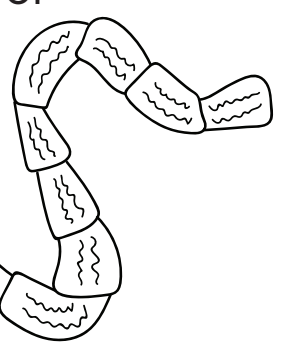

\section{THEY GET AROUND}

Parasites have taken up the globe-trekking lifestyle of modern humans. Sometimes when humans jet thousands of miles around the globe, parasites travel along. Managing the global spread of parasites that cause sickness in humans, livestock, pets, wildlife, and plants is an important challenge for biologists, health workers, and policy makers.

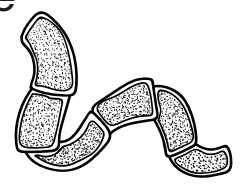




\section{PARASITES TELL US ABOUT THE HEALTH OF ECOSYSTEMS}

The presence of parasites in an ecosystem can indicate a healthy and diverse environment. Because parasitism is a natural and common way of life, scientists expect to find parasites when they study ecosystems. A missing parasite can be a sign that something is wrong in the environment. Parasites often rely on multiple host species to complete their life cycles. Finding a parasite in an area in one host tells us that healthy populations of that parasite's other hosts are probably also present. The world's climate is changing rapidly, forcing animals and plants to move to new areas. As host animals migrate, their parasites come along with them. Sometimes parasites switch hosts in order to survive. This is one way parasites escape the fate of a host species bound for extinction.
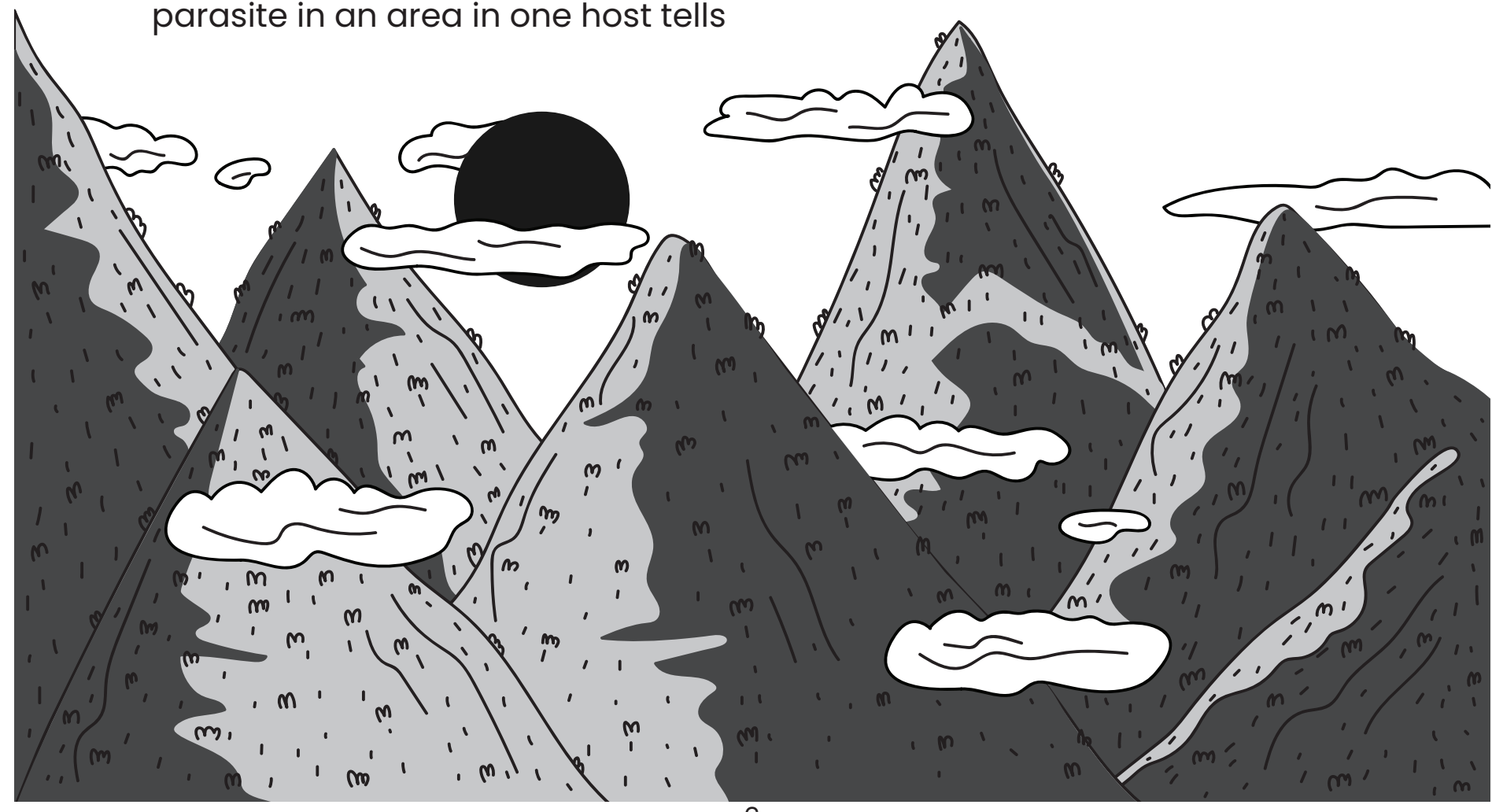


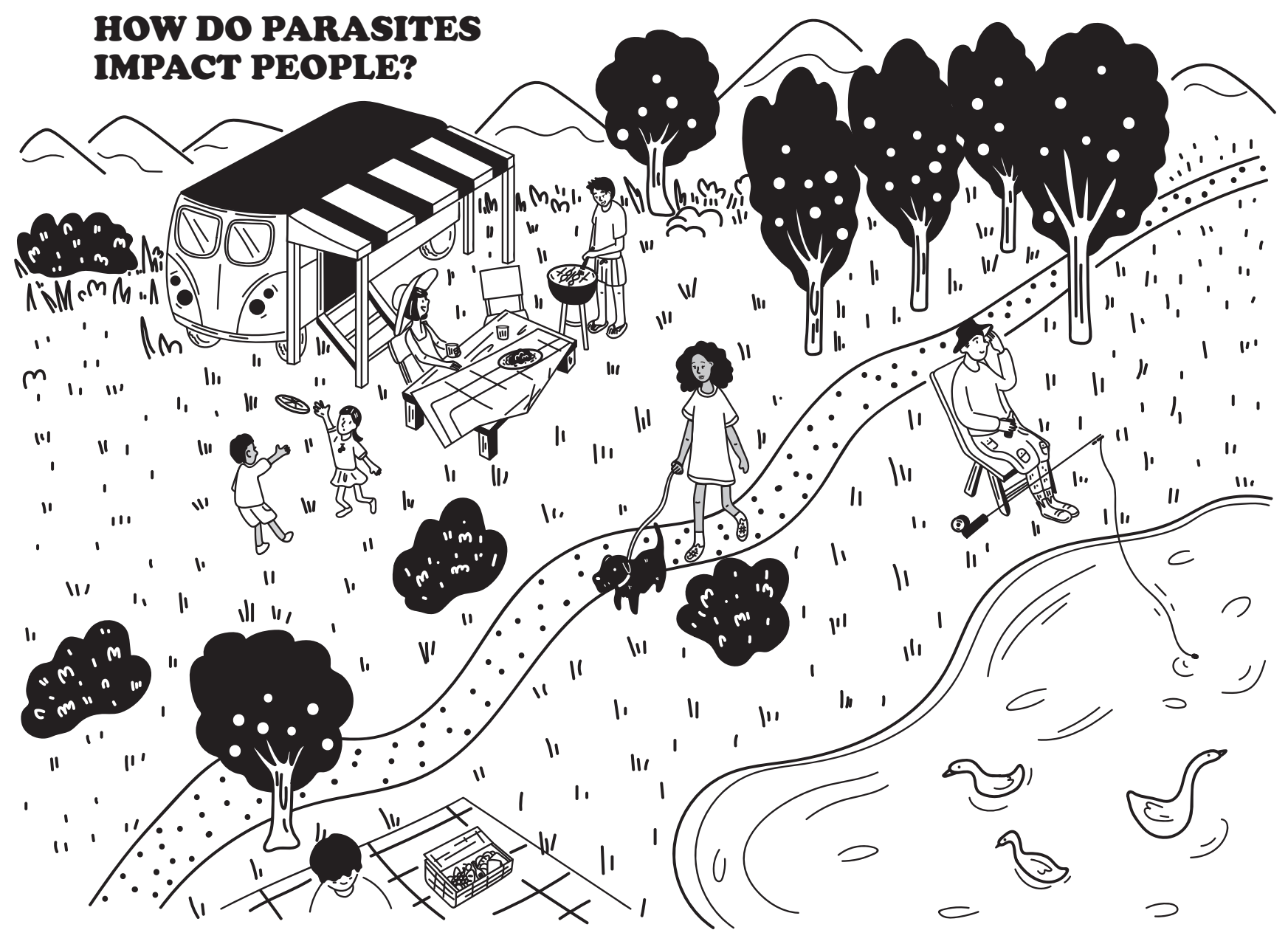

There are many parasitic diseases that affect human health. Lice occur worldwide, Rocky Mountain spotted fever occurs in North America, and Lyme disease occurs in North America, Europe, and Asia. Chagas disease occurs in North and South America. Humans' past interaction with parasites affects human health today. For example, some people of African descent possess sickle cell genes. Their ancestors were exposed to the malaria-causing parasite, Plasmodium falciparum. People with these genes get a milder form of malaria than others. However, they pass this gene on to their children who may suffer from sickle cell anemia. 


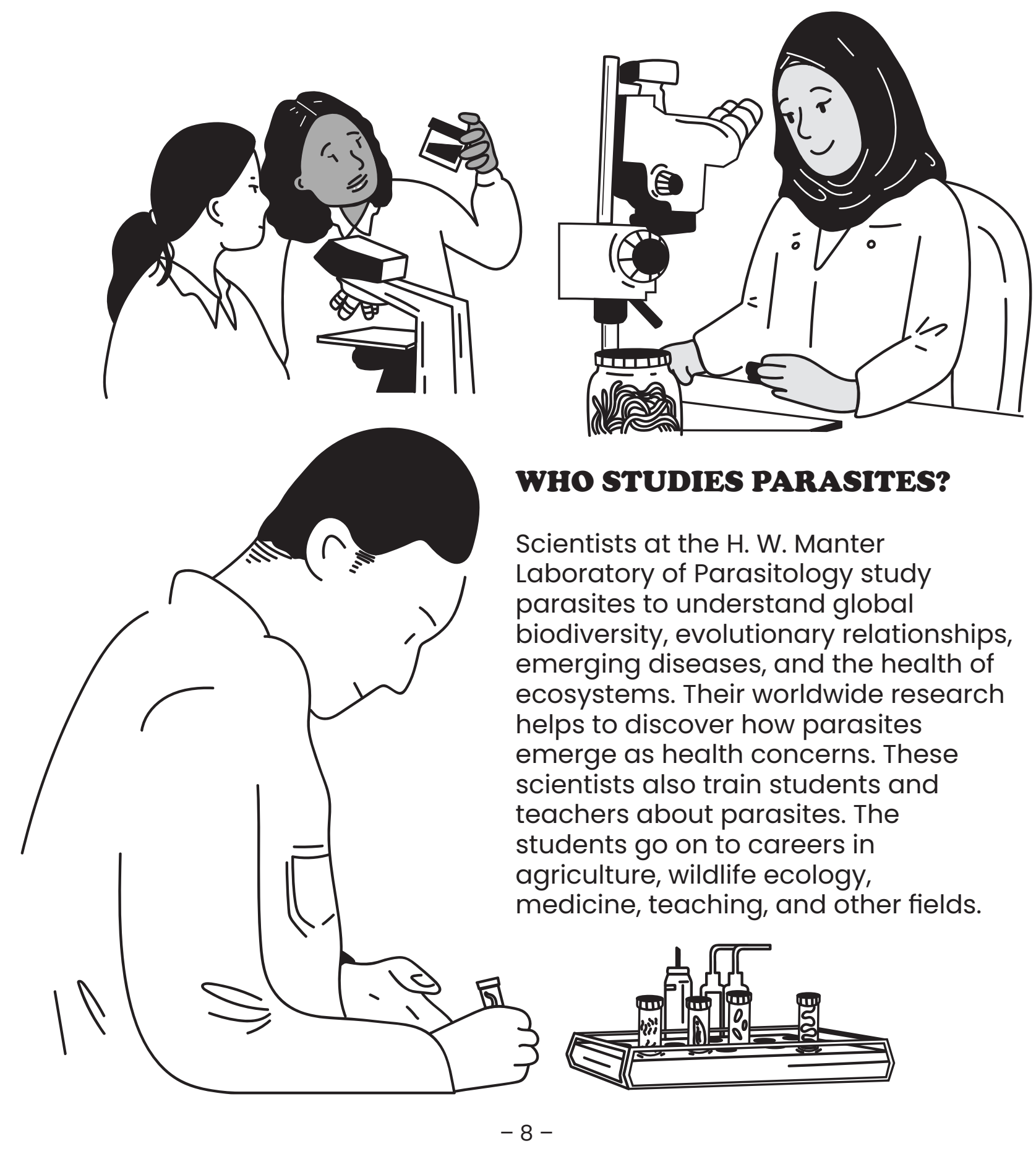




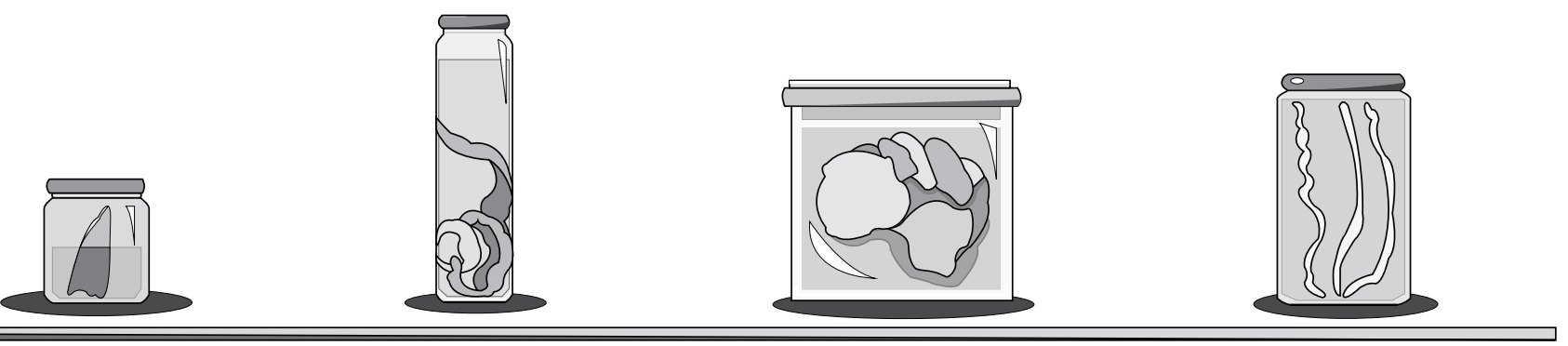

\section{PARASITES ARE}

\section{WORTH CARING ABOUT}

Science is the process of discovering new things. We know a lot about the parasites of humans, but we know far less about the parasites of other animals. Parasites are among the most numerous creatures on Earth.

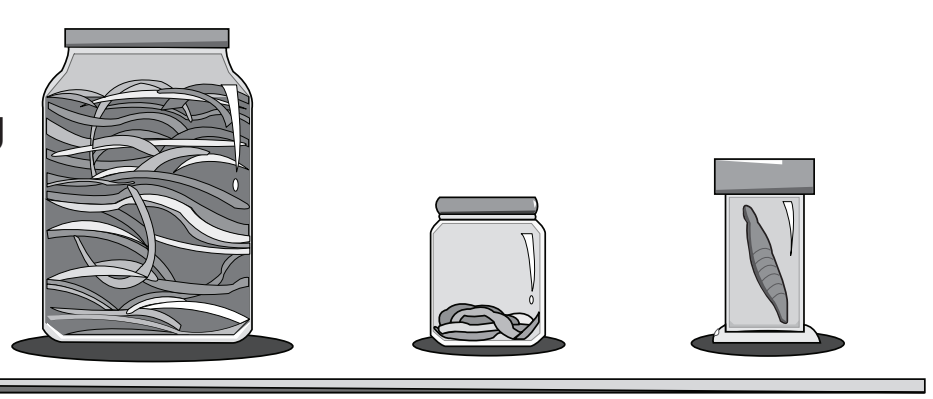

On a summer's day, it may seem like getting rid of all ticks and chiggers would be a great thing. But getting rid of all parasites would not make the world a healthier place. This would have unintended and unknown consequences. For example, parasites can regulate the populations of their hosts and they can positively affect soil health. Parasites are an essential component of biodiversity!
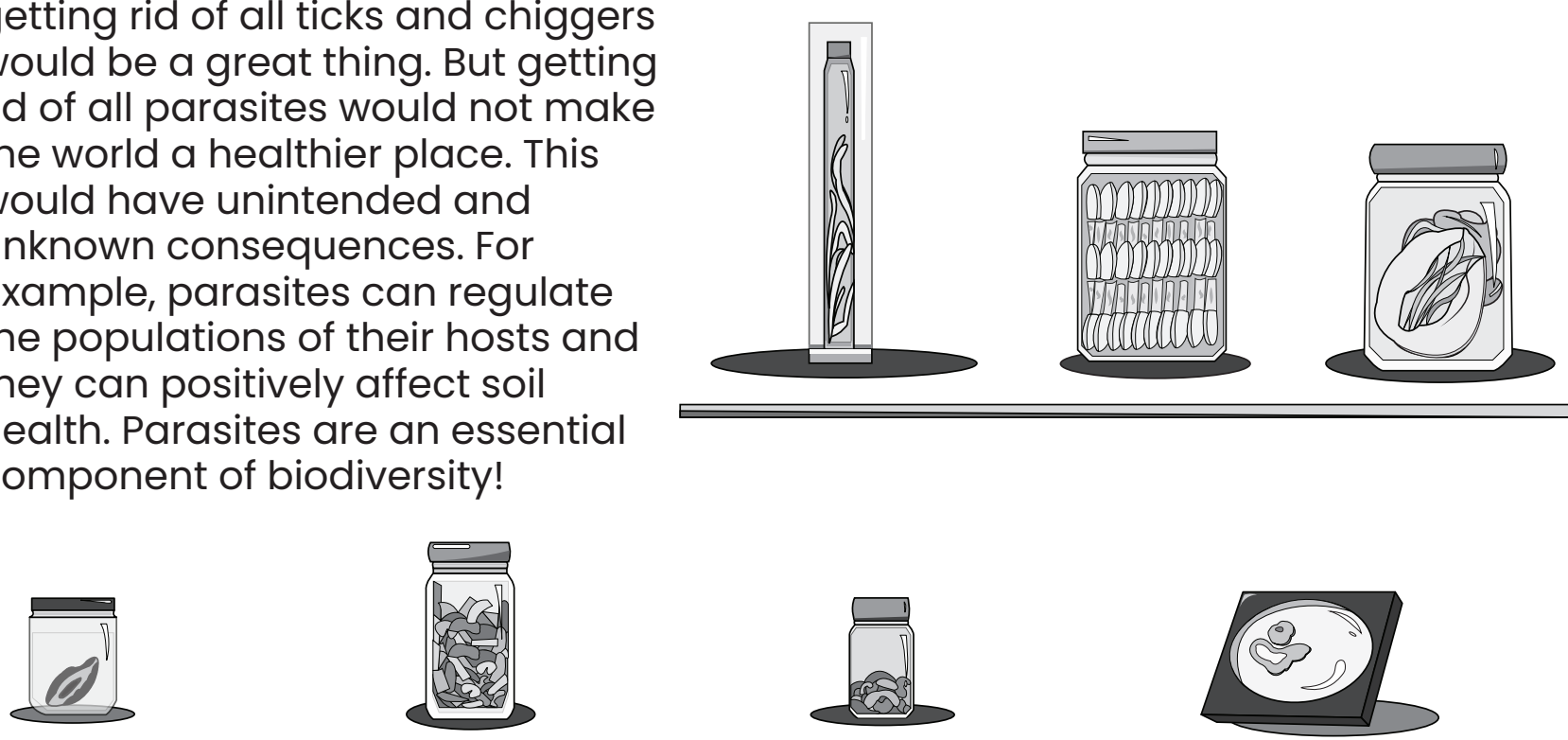


\section{THE H.W. MANTER LABORATORY OF PARASITOLOGY}

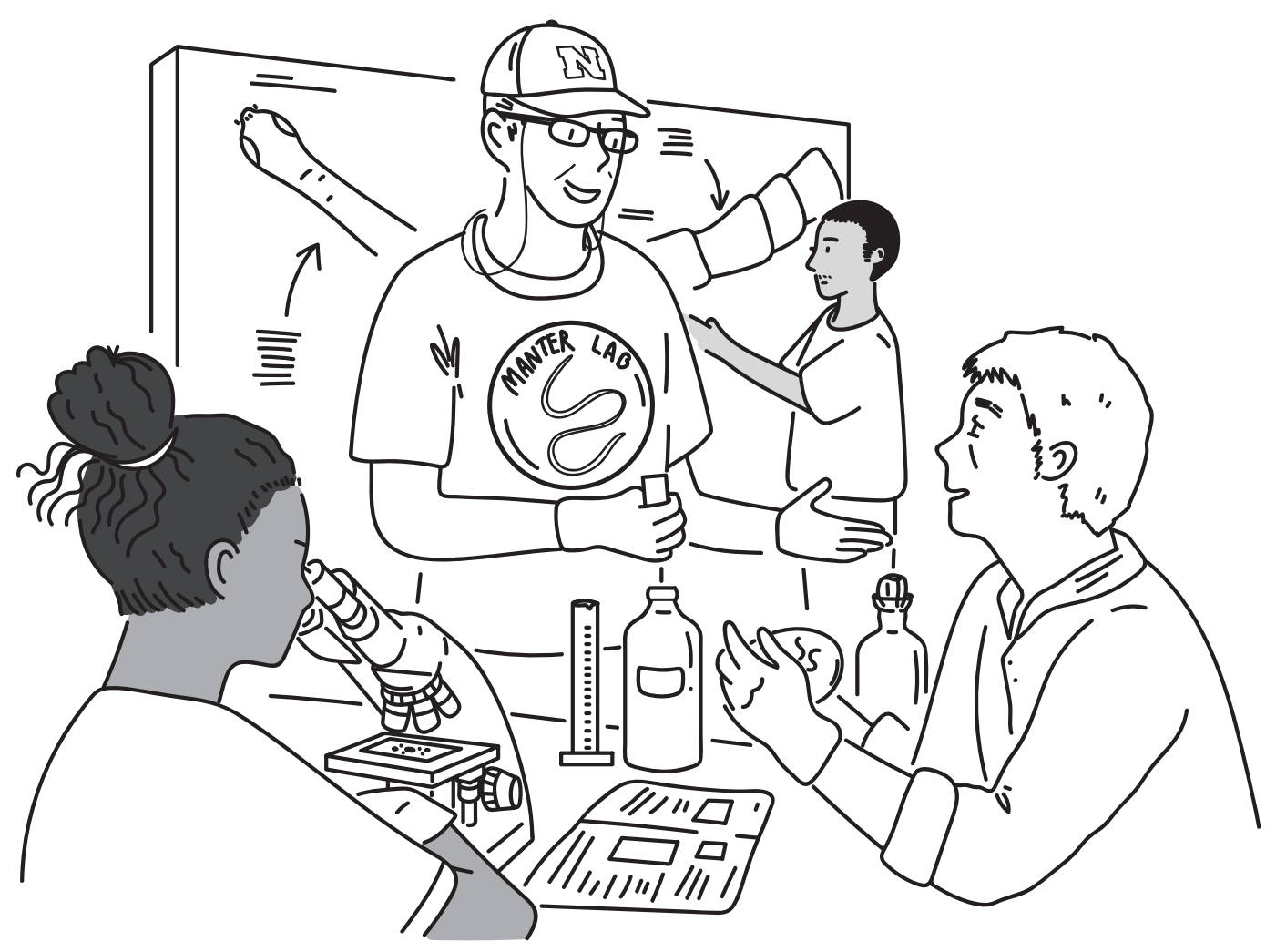

The H. W. Manter Laboratory of Parasitology is housed at the University of Nebraska State Museum. The lab conducts and supports research in parasite systematics and taxonomy with emphasis on parasites of mammals. It fosters studies in parasite biodiversity and provides state-of-the-art laboratories for research and long-term conservation studies. It also supports training and collects, archives, and distributes information about parasites throughout the world. For more information about the Manter Lab, go to hwml.unl.edu 

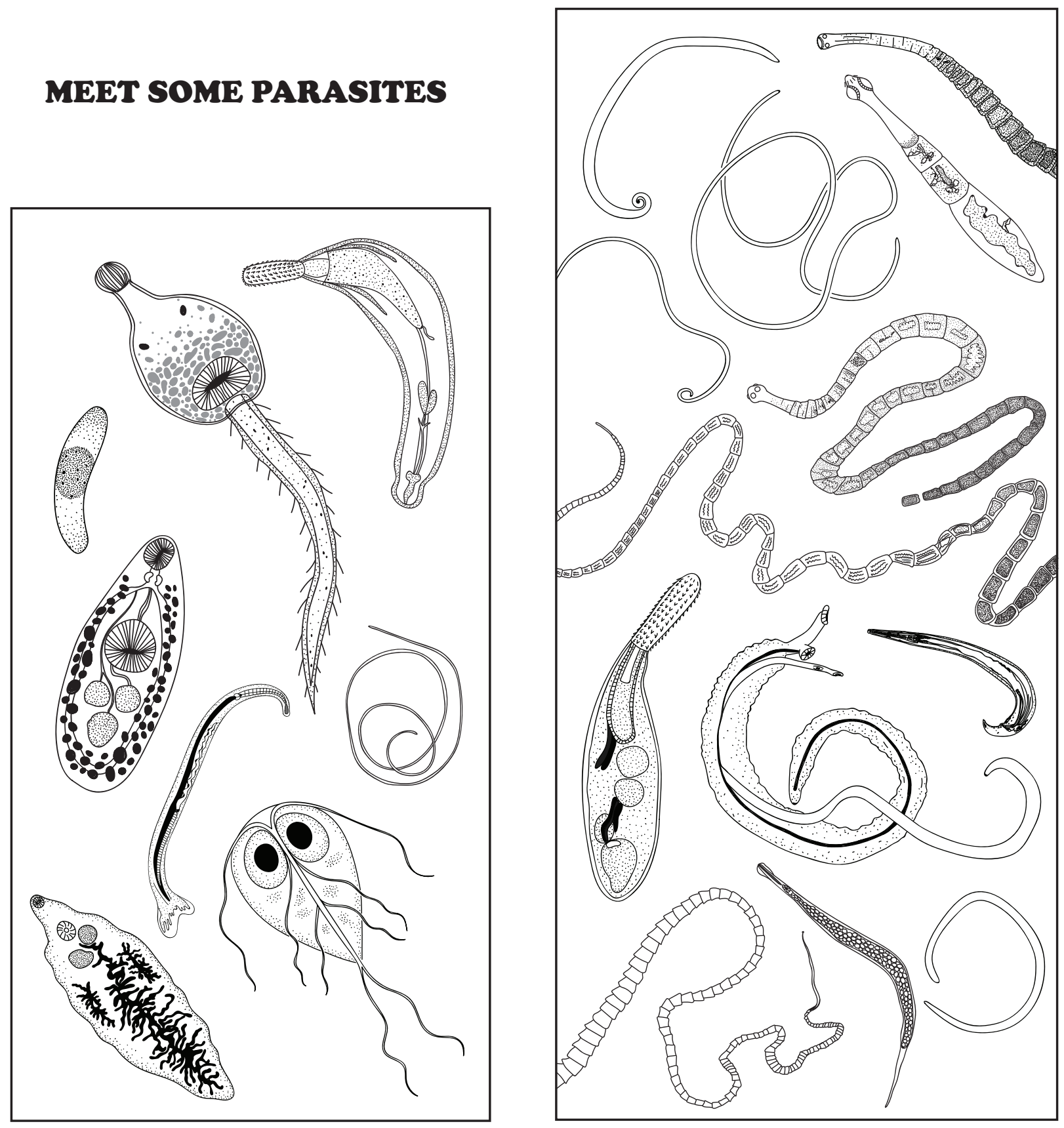


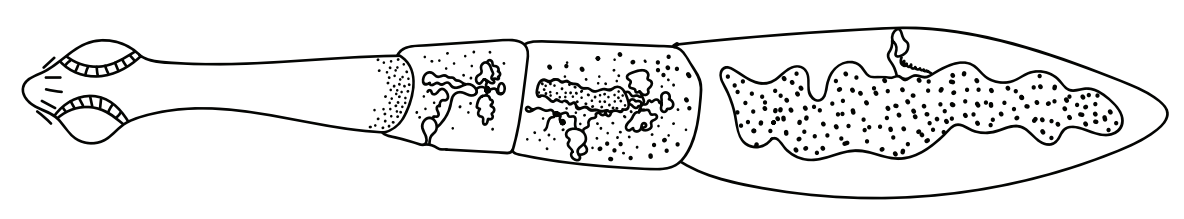

\title{
Echinococcus multilocularis
}

\author{
Fox tapeworm \\ Platyhelminthes \\ Size: $2-4 \mathrm{~mm}$ \\ Intermediate host: voles, lemmings, mice \\ Definitive host: wolves, coyotes, foxes
}

Fox tapeworm eggs are passed in feces, where they are accidentally ingested by rodents. Larvae penetrate the intestine of the rodent and migrate to the liver, where they form a continuously growing cyst. When a fox, dog, or coyote eats an infected rodent, it acquires hundreds of tapeworms. Children can become infected when they play with a dog that has the tapeworms. When a tapeworm egg is eaten by a person, it can develop in almost any body organ. Infection can go unnoticed for many years as the cysts grow slowly. The disease is becoming more common in areas where fox populations are increasing. 

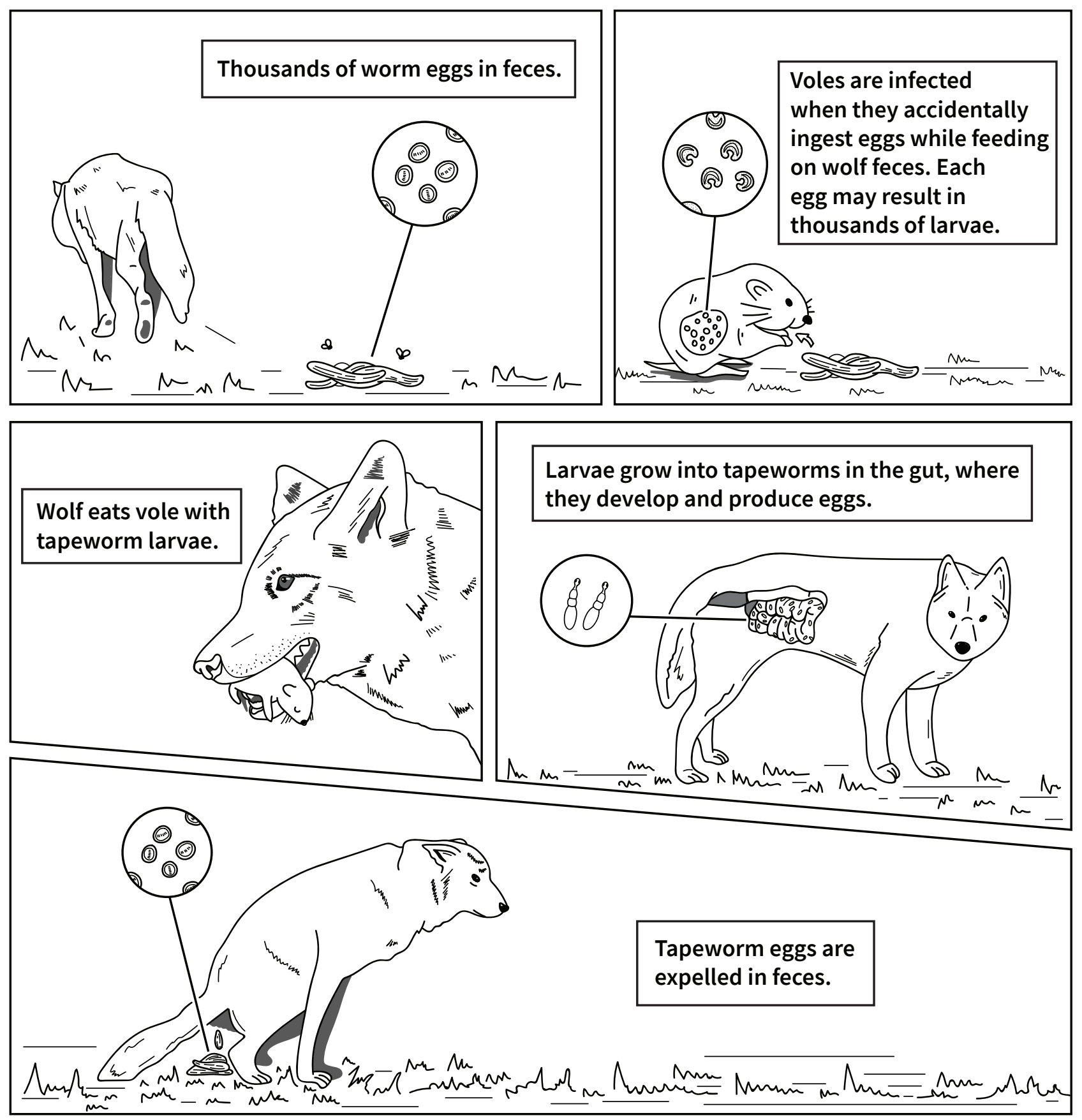

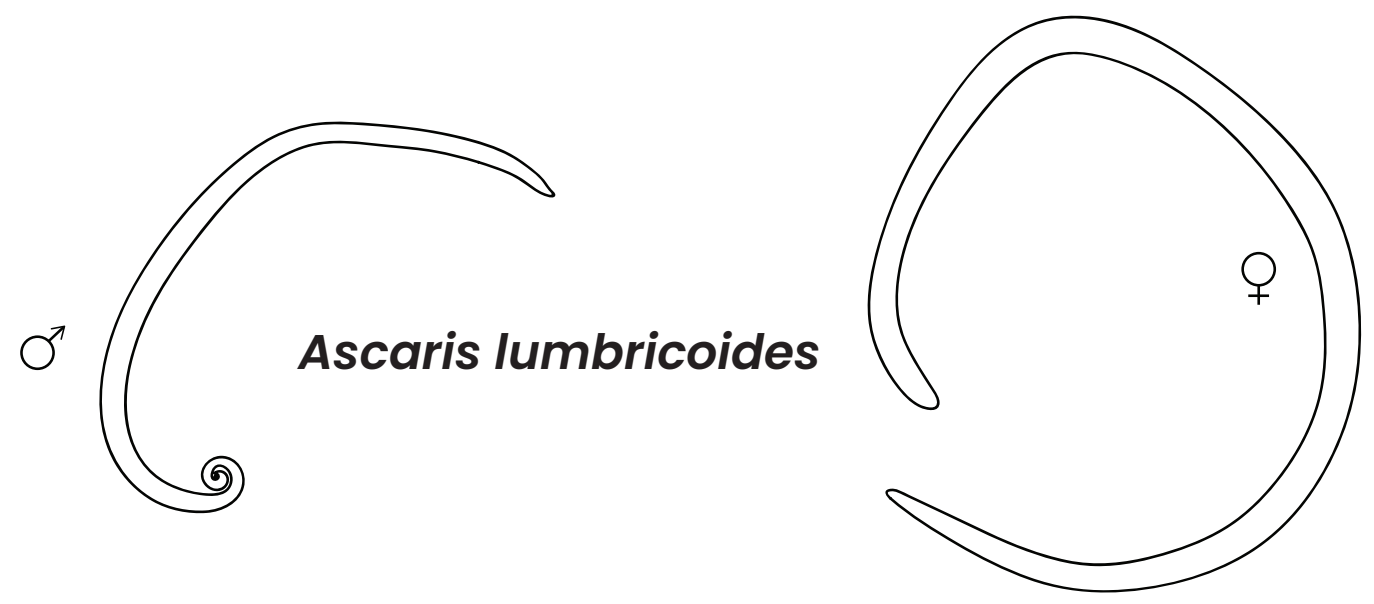

Large human nematode

Nemata

Size: 15-50 cm long, 2-5 $\mathrm{mm}$ wide

Host: humans

In the human intestine, female Ascaris worms produce eggs that are passed in feces. People become infected by consuming contaminated food or water. These worms are common in tropical and some temperate regions, and more than two billion people are infected. Some infected people show no symptoms, while others have mild discomfort. Children infected with numerous Ascaris have serious problems that can turn deadly. In areas lacking adequate sanitation, infections are common. 

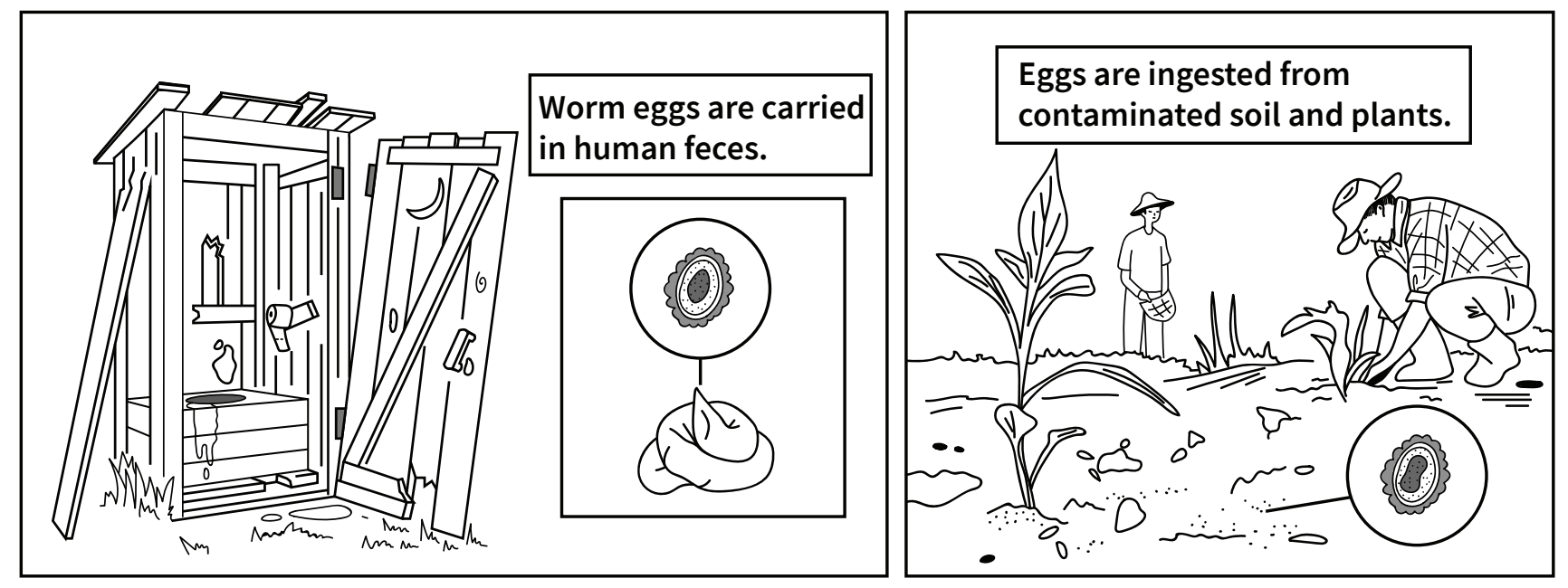

Eggs are swallowed and hatch in the intestine. Juveniles penetrate the intestinal wall and travel through the blood to the lungs.
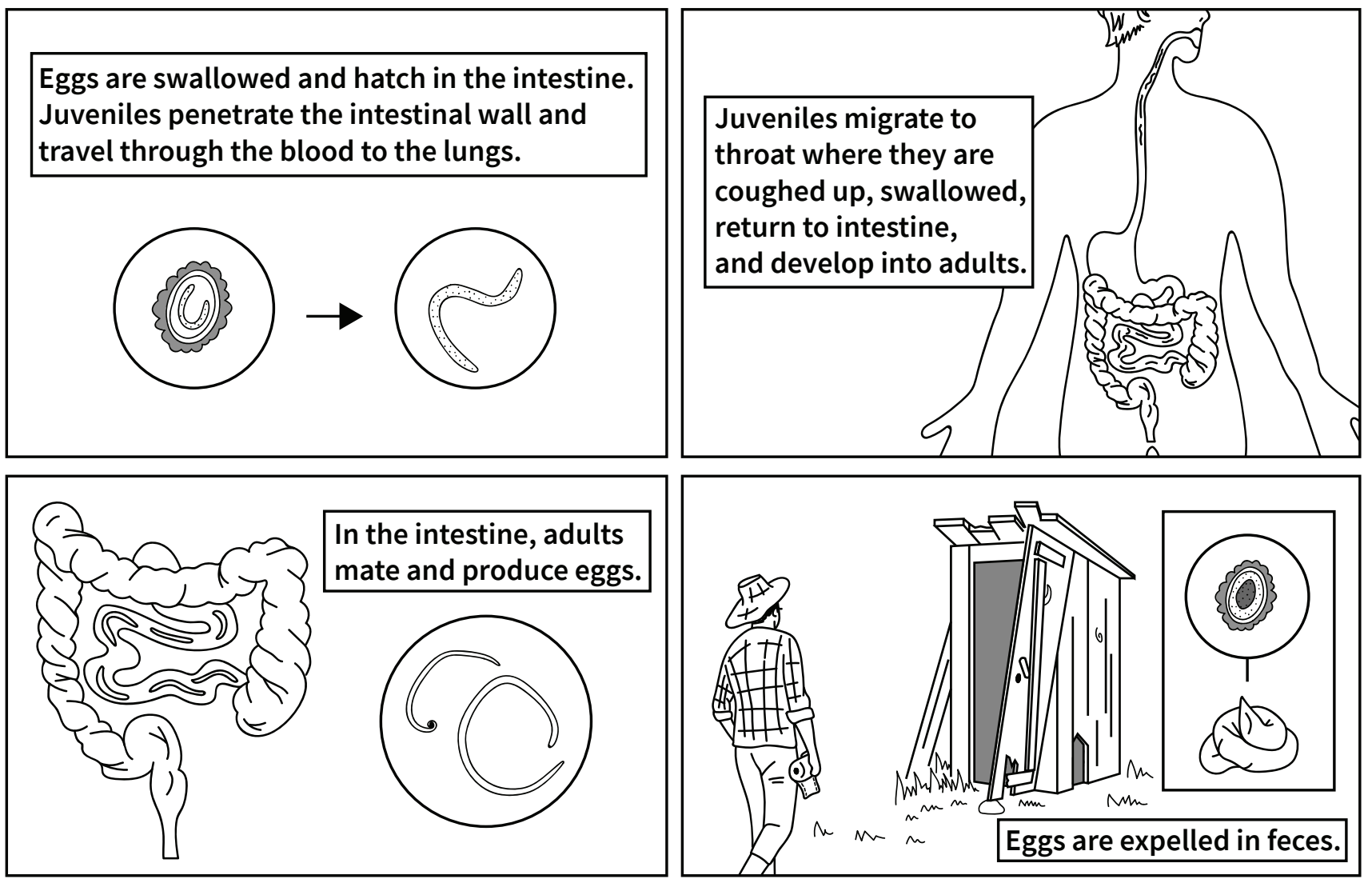


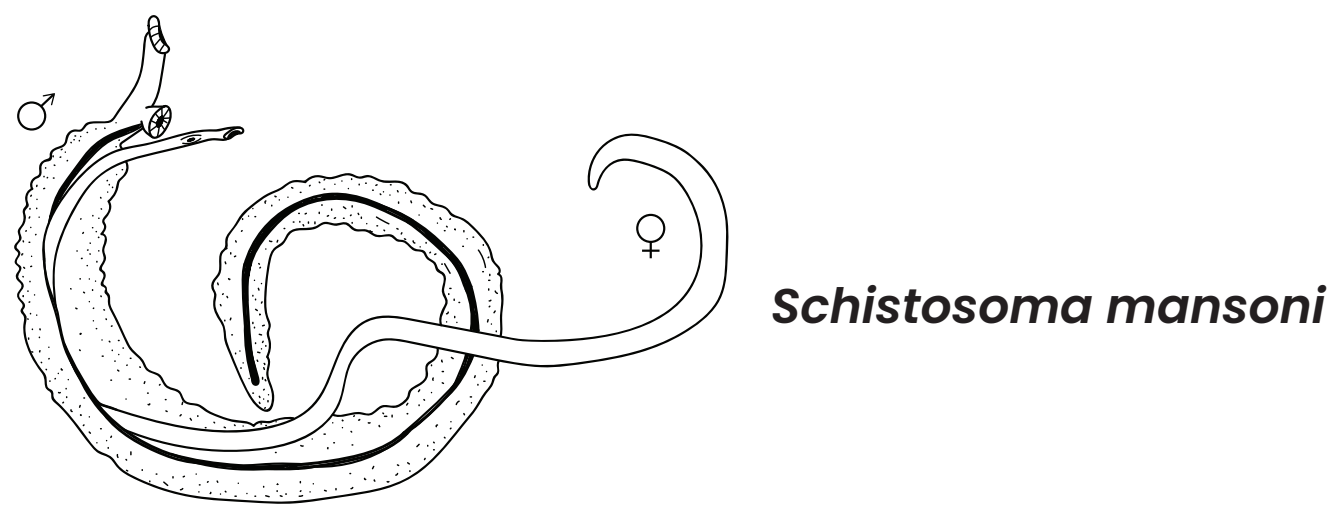

\author{
Blood fluke \\ Platyhelminthes
}

Size: 10-20 mm long, 800 micrometers to $1 \mathrm{~mm}$ wide

Intermediate host: Biomphalaria snails

Definitive host: rodents and primates

In humans, the adult schistosome worms live in the portal veins that drain the large intestine. Unlike other trematodes, these worms have separate sexes that are permanently attached to one another. Females lay hundreds of eggs per day that are passed into the blood. About two thirds of the eggs remain in the host, trapped in the liver and other organs. The rest are expelled in feces. In water, the first-stage larvae hatch and swim until they find a Biomphalaria snail. In the snail, they migrate to the digestive gland, multiply, and eventually produce second-stage larvae with $Y$-shaped tails. These larvae break out of the snail and swim to the surface of the water. They penetrate soft parts of the skin when people, usually kids, wade or swim in the water. 

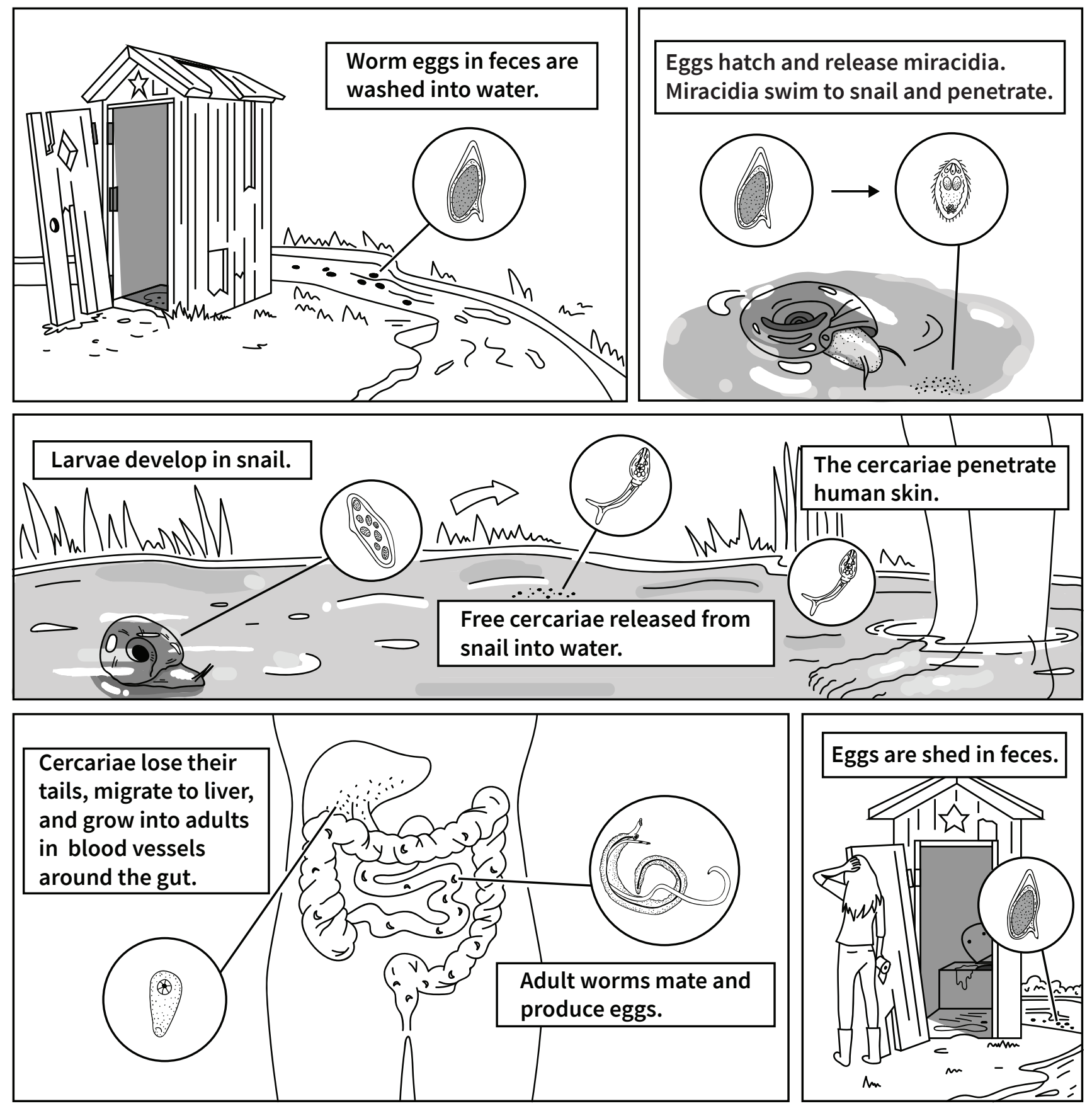


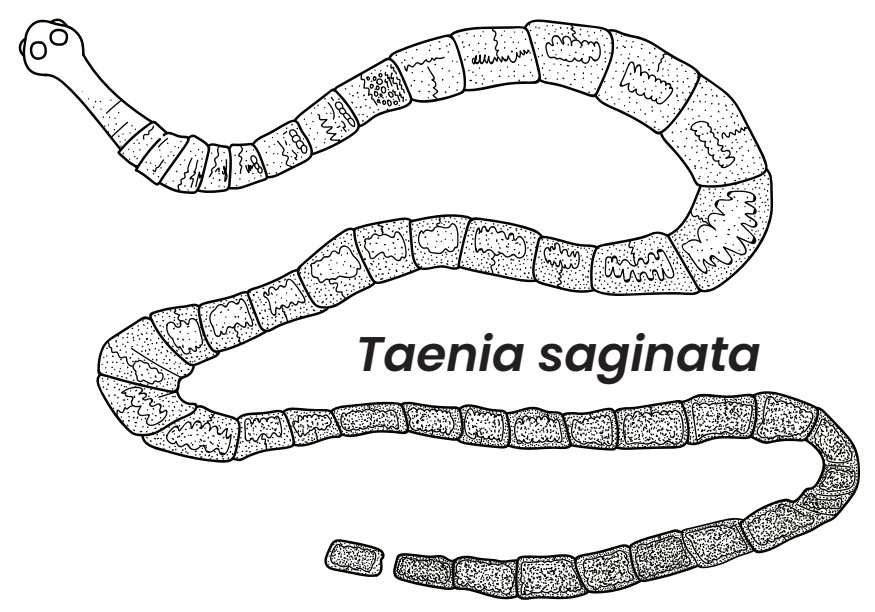

\author{
Beef tapeworm \\ Platyhelminthes \\ Size: 4-12 m long, $1 \mathrm{~cm}$ wide \\ Intermediate host: cattle \\ Definitive host: humans
}

Adult Taenia worms produce tens of thousands of eggs per day in the small intestine of humans. Eggs passed in feces can contaminate grazing areas in regions with poor sanitation. When cattle ingest the eggs, they hatch, penetrate the intestine, and travel to muscle tissue. When a person eats raw or undercooked meat, they may ingest the infective tapeworm larvae, which then grow into adults in their intestine. 

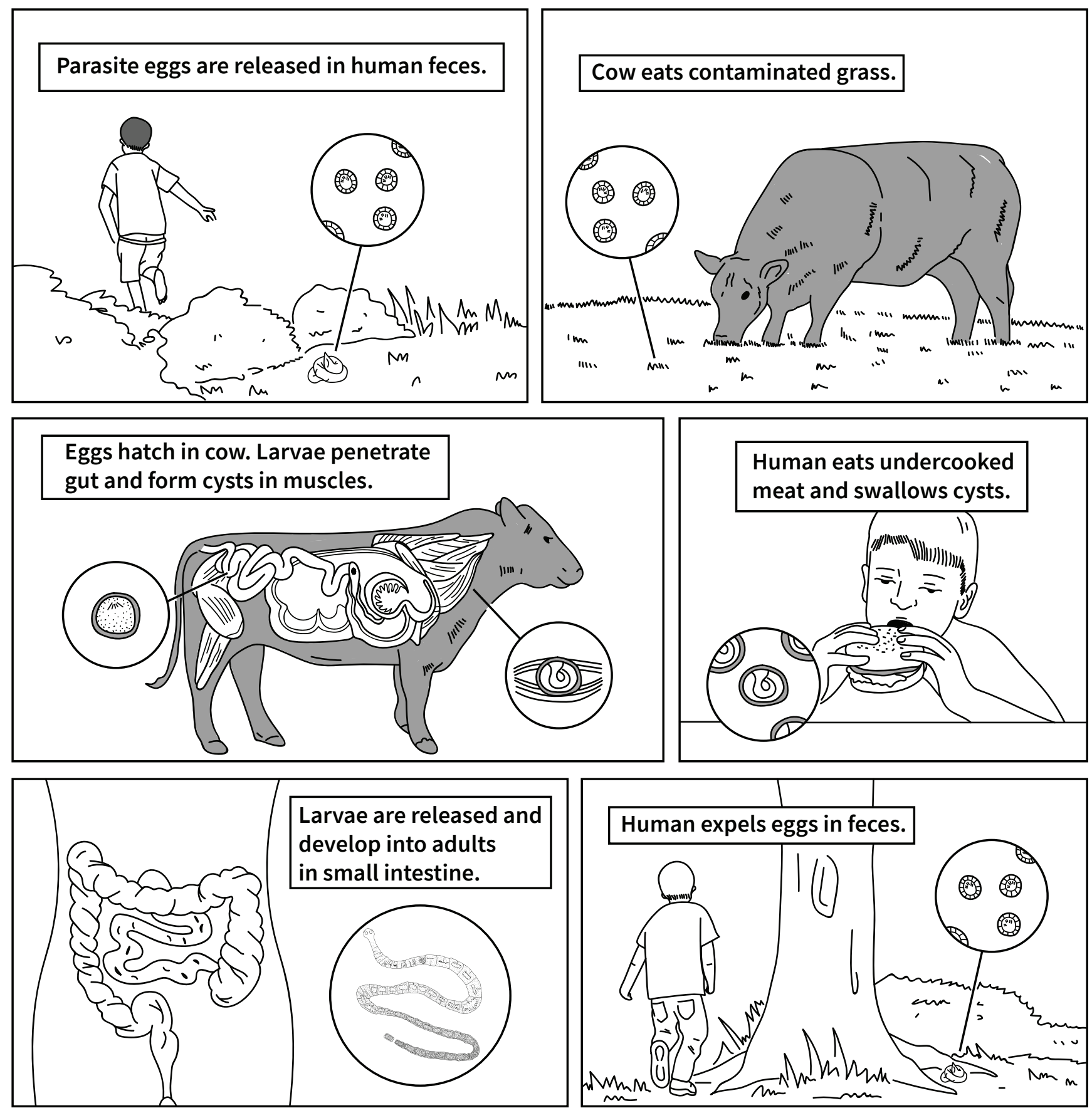
develop into adults in small intestine.
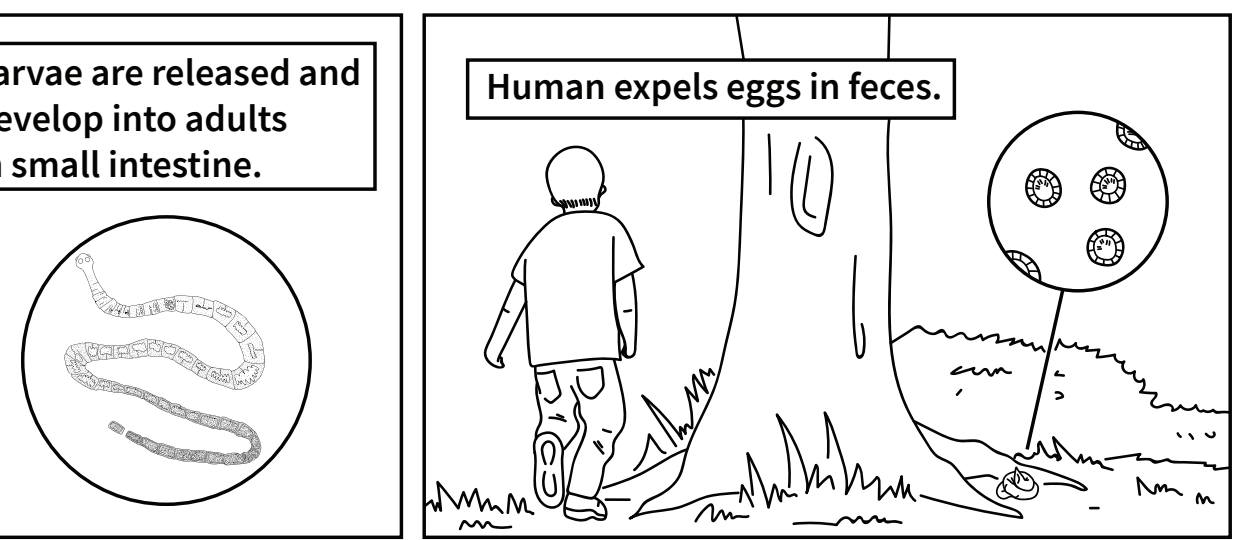

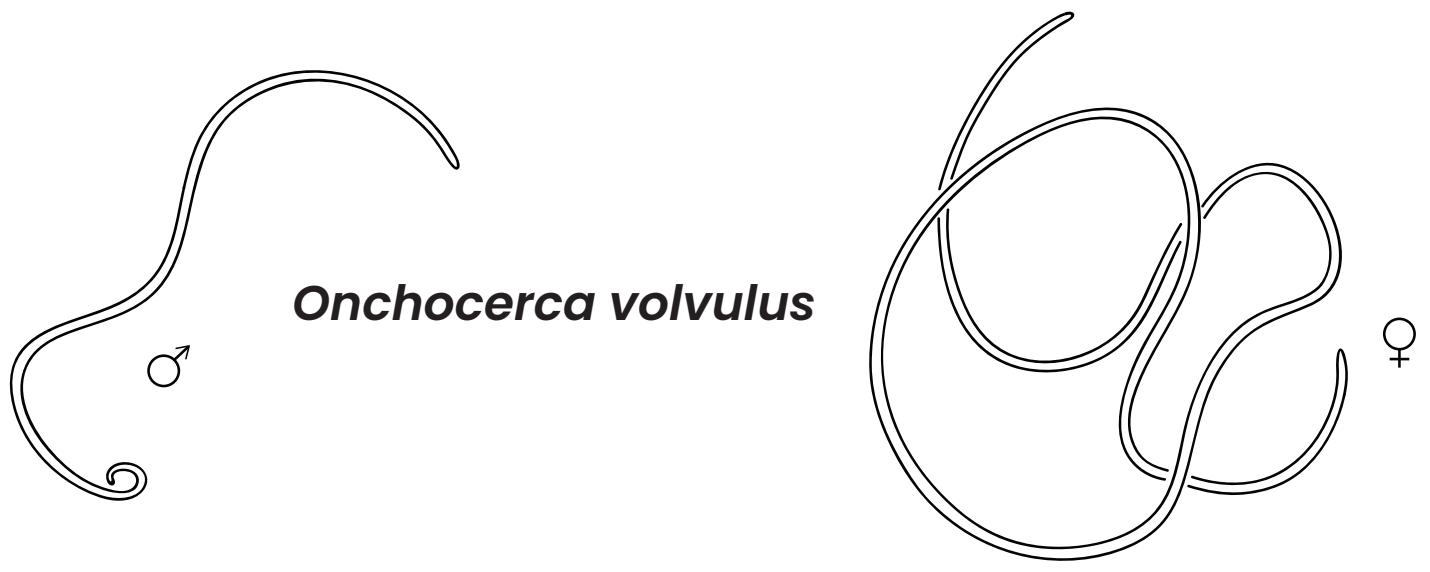

\author{
River blindness worm \\ Nemata \\ Size: $23-70 \mathrm{~cm}$ (females), $1.5-5 \mathrm{~cm}$ (males) \\ Intermediate host: blackflies \\ Definitive host: humans
}

Adults of this nematode live in fibrous nodules in the skin of their human hosts. Eggs hatch into juveniles that circulate in the skin. When a female blackfly takes a blood meal, the juveniles are ingested, go through three molts, and migrate to the fly's salivary glands. When the blackfly bites another person, the juveniles pass via the saliva into the host. The worms produce skin lesions in people, and severe effects occur when the juveniles cause inflammatory damage to the eyes, eventually resulting in blindness. 

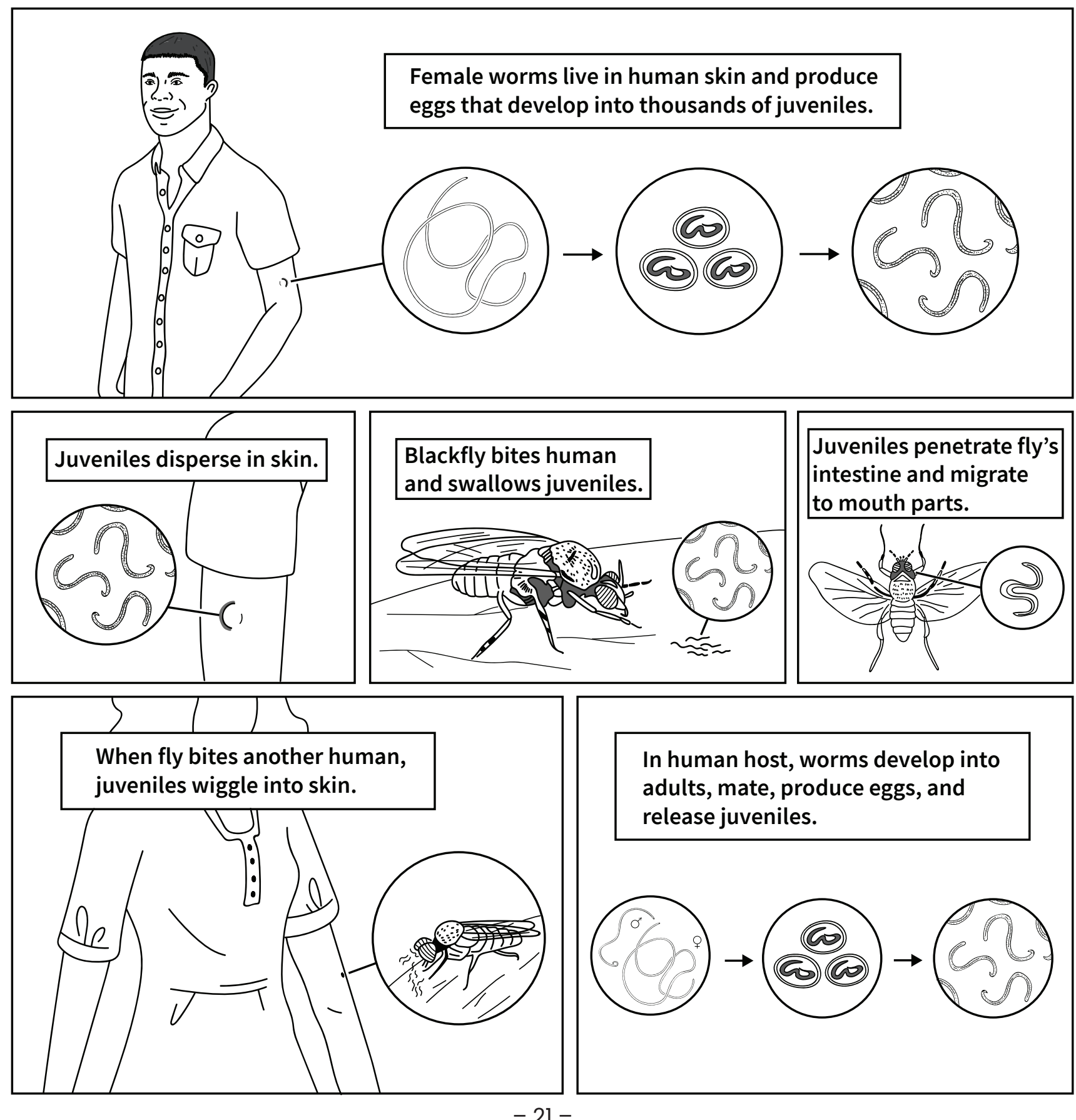

In human host, worms develop into adults, mate, produce eggs, and release juveniles.

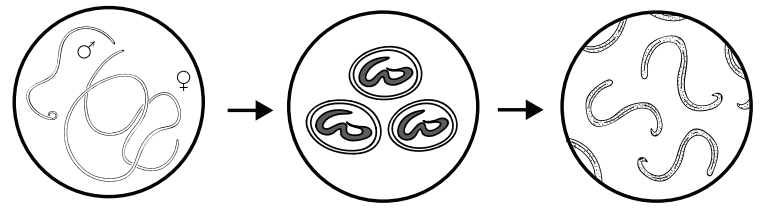




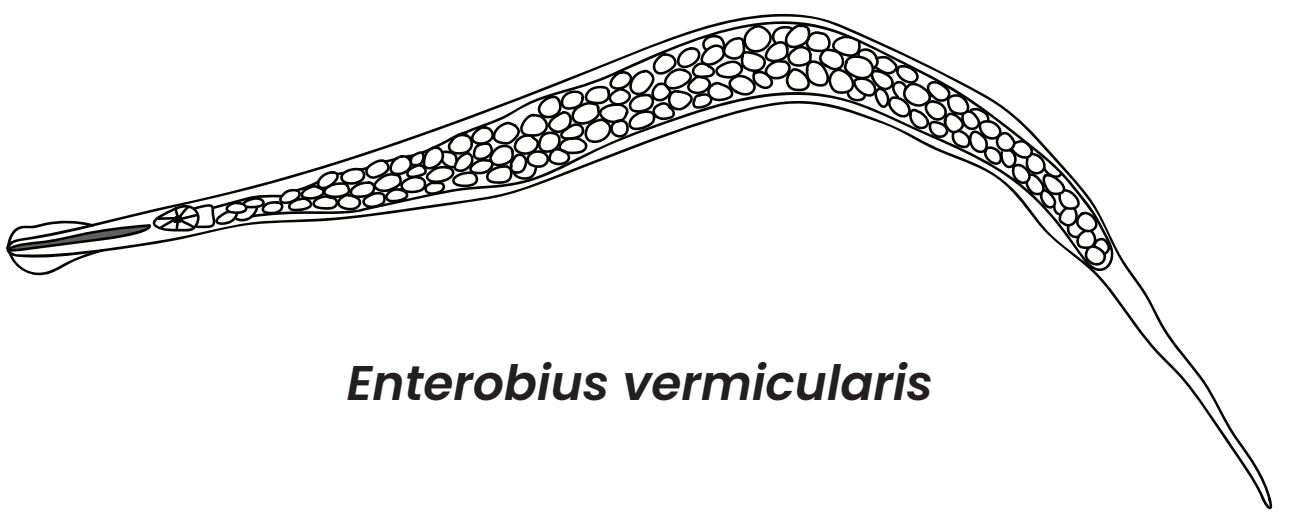

\author{
Human pinworm \\ Nemata \\ Size: 3-13 mm \\ Host: humans
}

Pinworms are one of the most common parasites of people. Pinworms live in the large intestine of the host, where they feed on bacteria.

Females often migrate out the anus and lay eggs on the surrounding skin. The eggs cause itchiness, so when people scratch themselves, eggs are picked up on their hands and can be dispersed easily in the environment. Once pinworms are established in households with children, eliminating them requires thorough cleaning. 


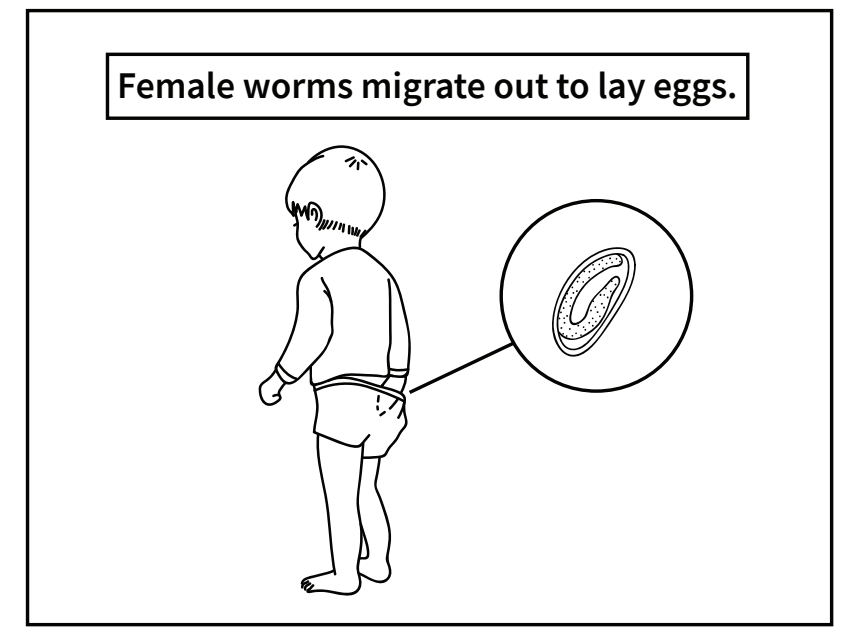

Eggs are transferred to hands and other surfaces.
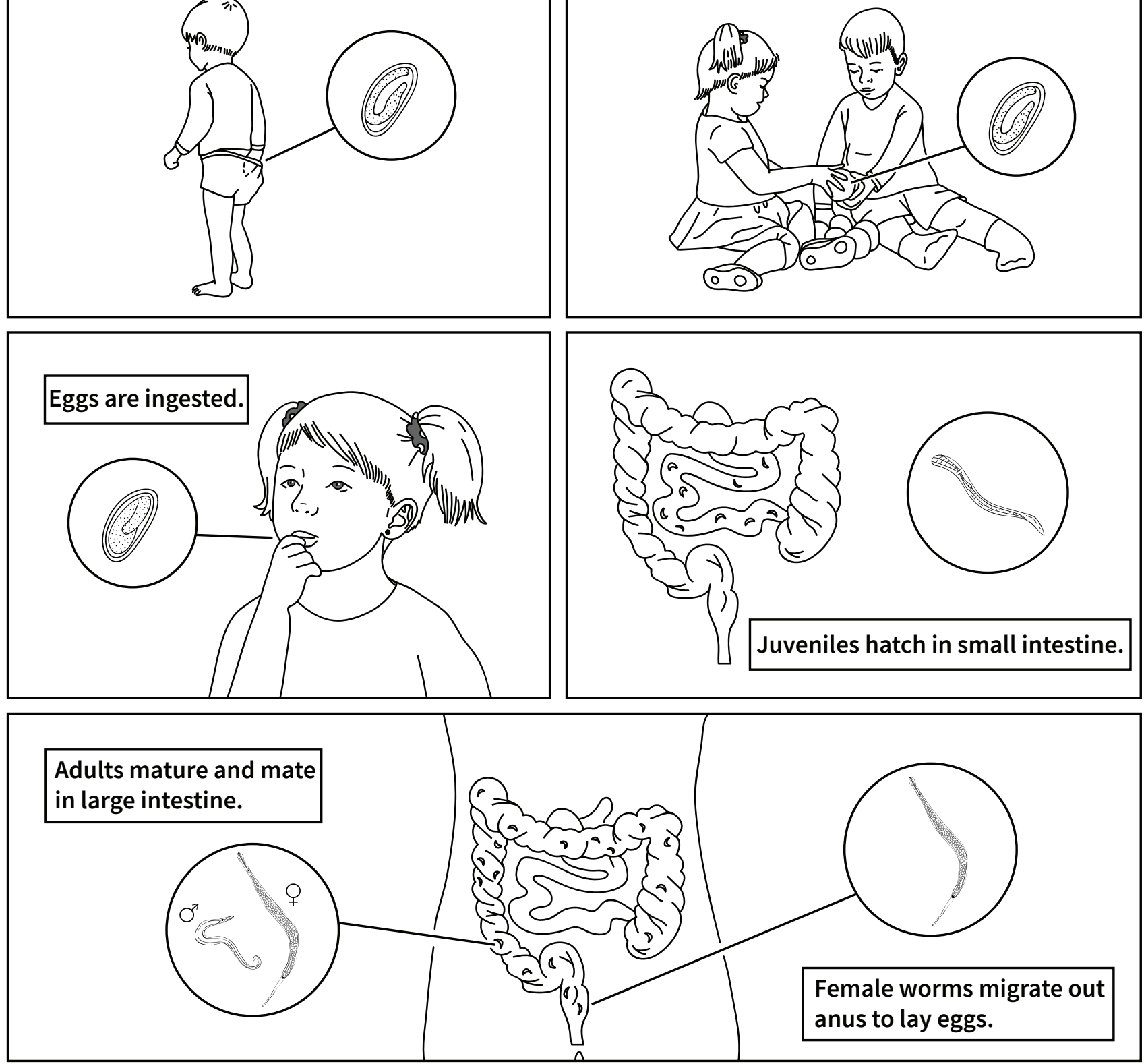

$-23-$ 


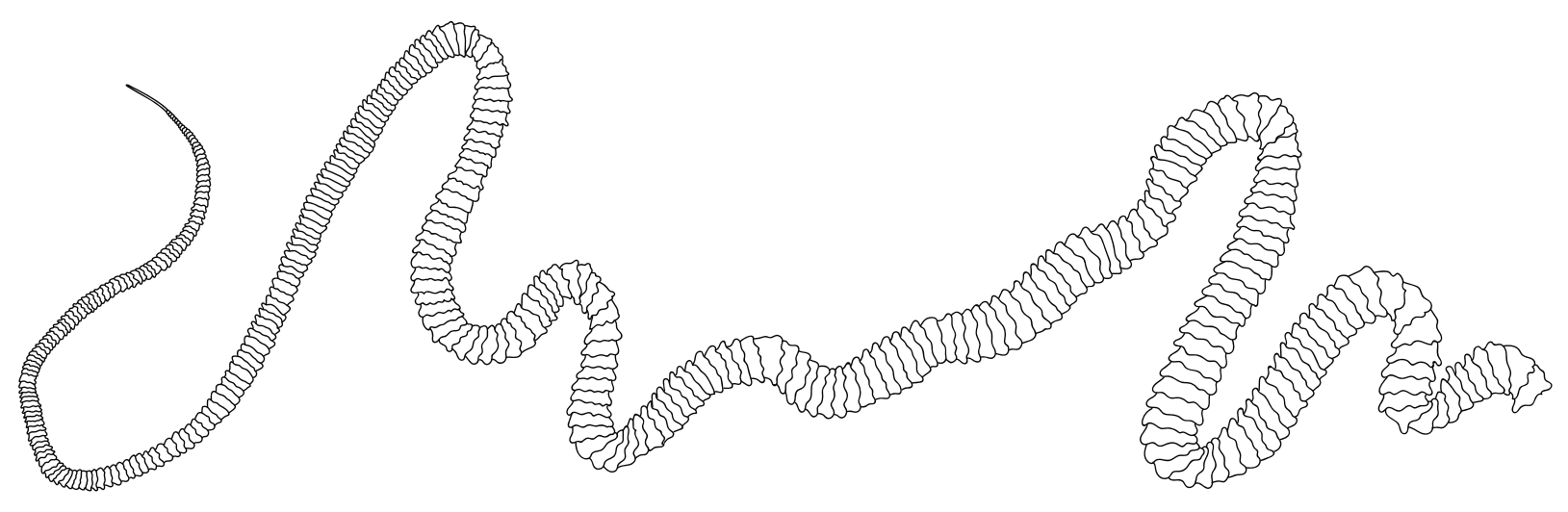

Tetragonoporus calyptocephalus

\begin{abstract}
Whale tapeworm
Platyhelminthes

Size: Up to $30 \mathrm{~m}$

lst intermediate host: marine crustaceans

2nd intermediate host: marine fishes or squid

Definitive host: sperm whales

This parasite is one of the longest tapeworms known. Little is known about its ecology, but related species have two intermediate hosts: the first are small zooplankton and the second are fish or squids that tapeworms mature in the small intestine and grow to their colossal size. Fecal analysis of sperm whales has shown that this tapeworm is more common in some regions, suggesting differences in the diet
\end{abstract} feed on them. When these hosts are eaten by sperm whales, the of these top marine predators. 

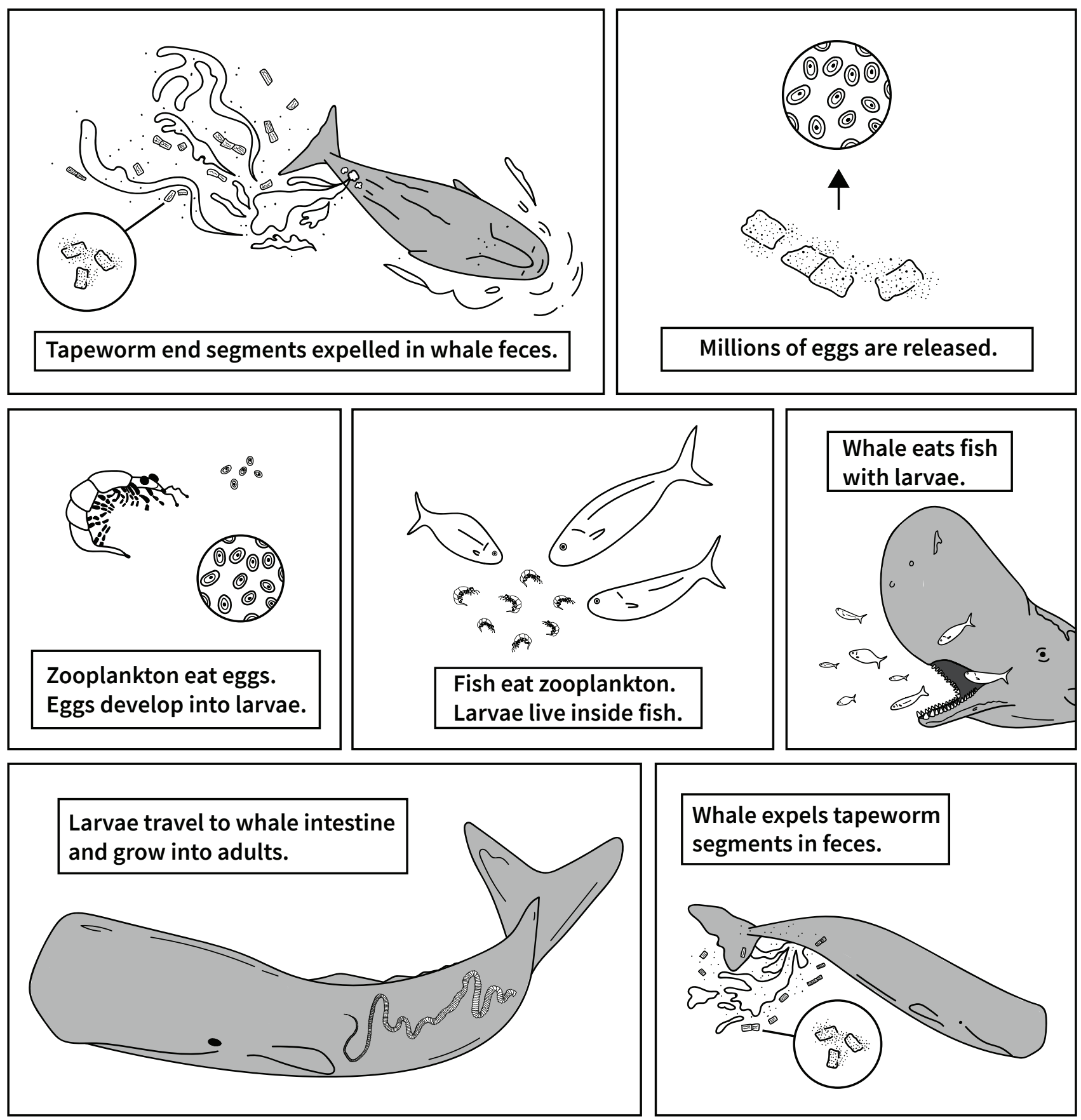

$-25-$ 


\section{Glossary}

anus is the opening from the intestine where waste products are expelled. asexual reproduction is the process of producing offspring without a sex partner.

biodiversity measures the variety and abundance of living organisms. blackfly in the genus Simulium carries the worm that causes river blindness.

carnivore is the group of mammals that includes dogs, cats, bears, and hyenas.

cercaria is the 3 rd developmental stage of a parasitic trematode. cestodes are tapeworms.

Chagas disease is caused by the parasitic protozoan Trypanosoma cruzi. chiggers are blood feeding mites, small relatives of ticks. climate change refers to the process of human-caused warming of Earth. cyst is a pocket within the tissue of a host that can contain a parasite. definitive host is the host in which parasites reproduce sexually. ecosystem includes the living and nonliving components of an environment.

ectoparasites are parasites that live or feed on the surface of their host. emerging diseases are new diseases caused by parasites or pathogens. endoparasite is a parasite that lives and feeds inside its host. evolutionary relationships describe how one organism is related to others. extinction is the loss of a species from the local or global biological community.

feces are the undigested remnants of animal food, expelled as waste. filarioids are long, thin nematodes adapted to live in the tissue of their host. fluke is a common name for parasitic flatworms in the group Trematoda. host is an organism that is infected with or is fed upon by a parasite. intermediate host is the host for immature parasites. kissing bugs are triatomid bugs, a group of insects that feed on blood. 
large intestine is the end part of the intestine, where feces are produced. larvae are the young and immature forms of worms, nematodes, and many insects.

lifeline is the life story of a parasite from the egg to the adult form.

Lyme disease is caused by a bacteria, Borrelia burgdorferi, and is transmitted by ticks.

malaria, caused by single-celled Plasmodium, is transmitted by mosquito bites.

microfilariae are the microscopic larvae of certain filarioid nematodes.

miracidia are the first larval stage of parasitic flatworms.

nematodes are very common smooth, string-like worms that live in soil and water.

parasitism is an evolved relationship in which one species benefits and the other is harmed.

platyhelminths are flatworms, a group that includes tapeworms and flukes.

population is a group of individuals of a species that forms a breeding community.

proglottids are the egg-producing segments of tapeworms.

protozoa are a group of single-celled microorganisms that belong to the phylum Protista.

Rocky Mountain spotted fever is caused by bacteria transmitted by ticks. sexual reproduction is when two individuals mate and generate offspring. sickle cell anemia is caused by a gene that changes red blood cells, making them less efficient at carrying oxygen.

small intestine is part of the gut where nutrients are absorbed. species diversity measures the richness of species at a particular location. tapeworms are long, segmented flatworms that live in the intestine of their hosts.

ticks are eight-legged arthropods that feed on the blood of a host. trematodes or flukes are parasitic flatworms that look like small leaves. zoonotic diseases are caused by pathogens that come from wild animals. zooplankton are microscopic animals that float in lakes, rivers, and oceans. 


\section{Resources for Youth}

Books

Belly-Busting Worm Invasions! Parasites That Love Your Insides! By T.E. Lewis Tilden. 2008. Franklin Watts.

Nasty Parasites. By Roxane Troup. 2019. Enslow Publishing, LLC.

New Guinea Tapeworms and Jewish Grandmothers: Tales of Parasites and People. 1987. By Robert D. Desowitz. W.W. Norton \& Co.

Parasite Rex: Inside the Bizarre World of Nature's Most Dangerous Creatures. By Carl Zimmer. 2001. Simon and Schuster.

Parasites: The Inside Story. By Scott Gardner, Judy Diamond, and Gabor Racz. 2022. Princeton University Press.

The Gross Science of Lice and Other Parasites. By Keith Olexa. 2018. The Rosen Publishing Group.

What's Eating You? Parasites - The Inside Story by Nicola Davies. 2007. Candlewick Press.

Watch Your Mouth! And Discover your Amazing Microbes. By Linda Allison, Rebecca Smith, and Judy Diamond. 2016. Bitingduck Press.

\section{Comics}

C'Rona Pandemic Comics. 2021. By B. Hall and team. U. of Nebraska Press. Mosquitoes Suck. 2021. By K. Bruna, S. Erikson, L. Bartholomay. U. of Nebraska Press. Occupied by Microbes. 2019. By J. Diamond and the Biology of Human team. Zea Books. Carnival of Contagion. 2017. By B. Hall, C. Zimmer, J. Diamond. 2017. U. of Nebraska Press. World of Viruses. 2012. By J. Diamond and team. University of Nebraska Press.

\section{Activities}

Download the free WONDERWISE Parasite Sleuth activity book at http://wonderwise.unl. edu/12parasi/parasite.htm

Cool activities for kids.

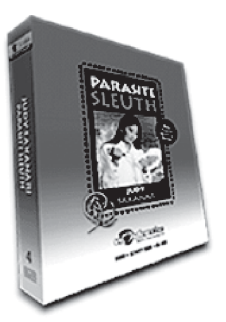

Wonderwise was awarded First Place for the Advancement of Learning Through Broadcasting by the National Education Association for Children's Programming 1998. Wonderwise is based upon work supported by the National Science Foundation under Grant No. 9909496. 


\section{About the authors and illustrator}

Scott L. Gardner is Curator of the H. W. Manter Laboratory of Parasitology and Professor of Biological Sciences at the University of Nebraska.

Judy Diamond is Professor of Libraries at the University of Nebraska and Curator of Informal Science Education at the University of Nebraska State Museum.

Gabor Racz graduated from the Eötvös Loránd University in Budapest studying research biology. During his career he worked in the Hungarian Natural History Collection and the Museum of Southwestern Biology. He is currently at the University of Nebraska State Museum.

Brenda Lee is a graphic artist with degrees in Graphic Design from the University of Nebraska and Illustration Design from The One Academy, Penang, Malaysia. 

这

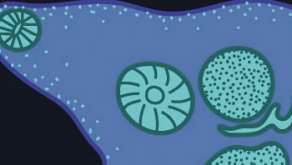

2)

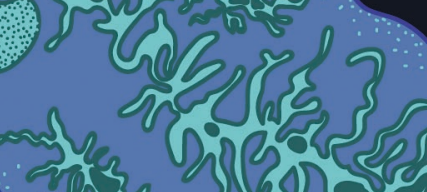

$\circ$
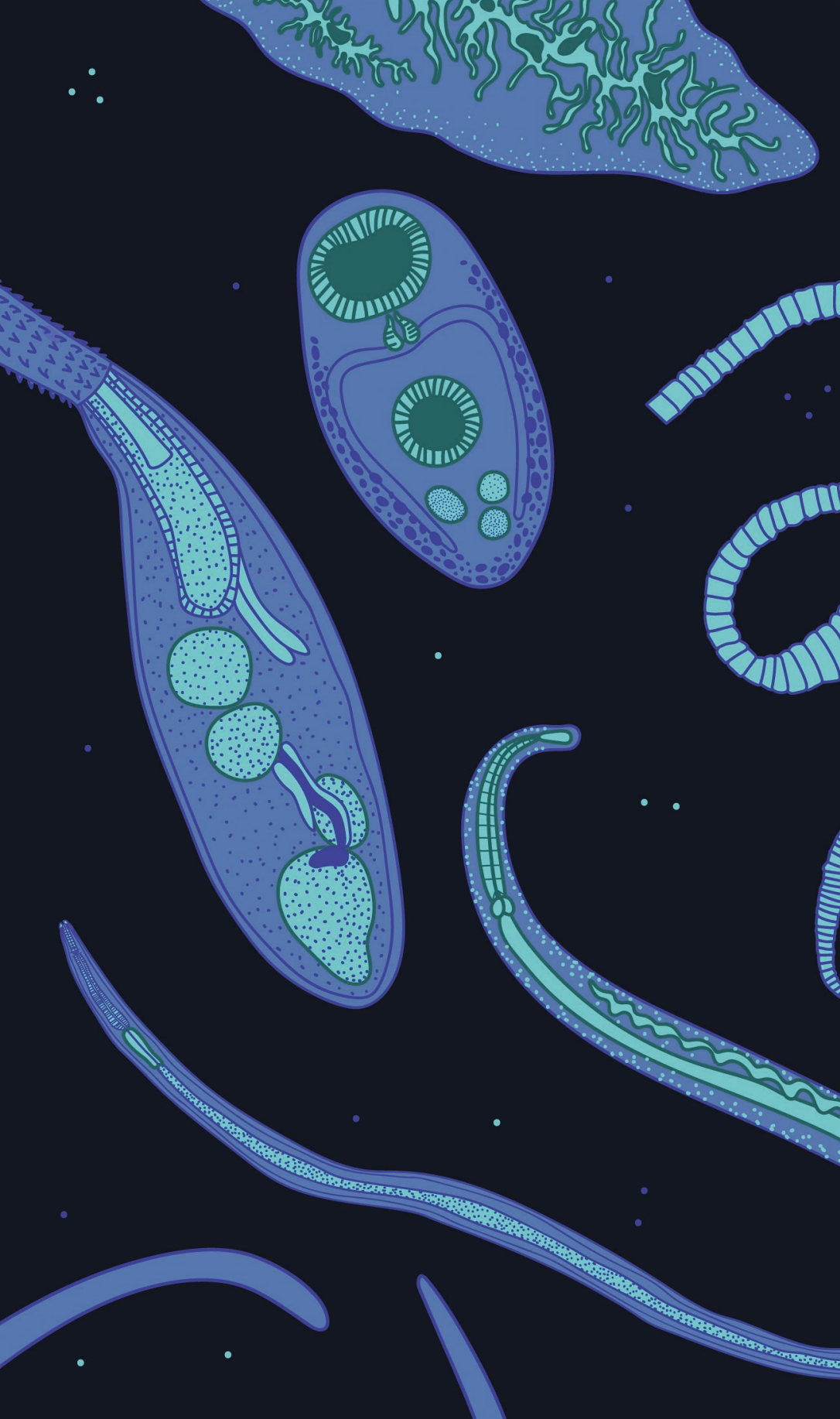